\title{
Testing of an Integrated lodine Scrubber and Polishing Bed System
}

\section{Nuclear Technology}

Research and Development

Approved for public release. Distribution is unlimited.

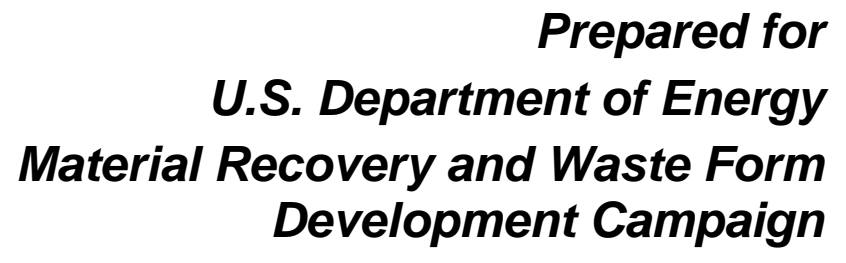

R. T. Jubin, S. H. Bruffey and J. A. Jordan

Oak Ridge National Laboratory

28 September 2018

NTRD-MRWFD-2018-000195

ORNL/TM-2018/1000 



\section{DISCLAIMER}

This information was prepared as an account of work sponsored by an agency of the U.S. Government. Neither the U.S. Government nor any agency thereof, nor any of their employees, makes any warranty, expressed or implied, or assumes any legal liability or responsibility for the accuracy, completeness, or usefulness, of any information, apparatus, product, or process disclosed, or represents that its use would not infringe privately owned rights. References herein to any specific commercial product, process, or service by trade name, trade mark, manufacturer, or otherwise, does not necessarily constitute or imply its endorsement, recommendation, or favoring by the U.S. Government or any agency thereof. The views and opinions of authors expressed herein do not necessarily state or reflect those of the U.S. Government or any agency thereof. 



\section{SUMMARY}

In 2016 an initial engineering evaluation and design of the off-gas abatement systems required for a hypothetical $1000 \mathrm{t} / \mathrm{yr}$ used nuclear fuel (UNF) reprocessing facility treating $5 \mathrm{yr}$-cooled, $60 \mathrm{GWd} / \mathrm{tIHM}$ UNF was completed. In this study two types of silver-based iodine sorbents were considered. The first was a silver-exchanged mordenite (AgZ), and the second was a silver-functionalized silica aerogel. In the initial design of the dissolver off-gas (DOG) iodine capture beds, the sorbent capacity was assumed to be $40 \mathrm{mg} \mathrm{I/g}$ sorbent. The total iodine released from the fuel, used as input for the design of the DOG system, was $1.635 \mathrm{~kg} /$ day. Tramp halogens increased this to $\sim 5.1 \mathrm{~kg} /$ day on an iodine equivalent basis. The daily consumption of iodine sorbent was $\sim 166 \mathrm{~kg}$ (including the mass transfer zones that have lower iodine loading). The iodine capture system was designed to utilize five beds in parallel. In this design each bed was $\sim 1 \mathrm{~m}$ in diameter and $1.5 \mathrm{~m}$ long. This design allowed the beds to remain on line for 20 days, but at that point all five beds would need to be replaced, resulting in considerable material handling.

It was proposed that the bed life could be extended and the number of parallel beds reduced if an aqueous iodine scrubber preceded the solid sorbent iodine capture beds. The testing described in this report was intended to provide an evaluation of an integrated system in which bulk iodine would first be removed by an aqueous $\mathrm{NaOH}$ scrubber with a target iodine decontamination factor (DF) of 10 to 50. This would reduce the sorbent usage by 90 to $95 \%$ and significantly reduce the associated frequent remote handling of the iodine filter beds. The effluent from the scrubber would then be passed through an AgZ sorbent bed to remove residual iodine. The integration of these unit operations was intended to demonstrate an iodine DF of $>1000$, which would facilitate regulatory compliance with regards to total volatile radionuclide emission from a reprocessing facility.

Initial baseline performance testing of the scrubber system includes the characterization of $\mathrm{CO}_{2}$ removal by the aqueous $\mathrm{NaOH}$ scrubber as a function of temperature, caustic concentration, packing length, liquid-to-gas mass ratio, and liquid flow rate. It was found that when the column was well wetted, very high $\mathrm{CO}_{2}$ DFs were achieved (>650 and potentially as high as 15,000), preventing the ability to elucidate the effects of each specific variable tested. The L/G ratio in this system was not representative of typical $\mathrm{L} / \mathrm{G}$ ratios found in industrial-scale scrubber systems. By significantly lowering the liquid recirculation rate to the point that column wetting was marginal, some significant variations in the $\mathrm{CO}_{2} \mathrm{DF}$ or $\mathrm{CO}_{2}$ effluent concentrations could be observed. The additional tests conducted under these more adverse conditions still showed $\mathrm{CO}_{2} \mathrm{DFs}>100$. The only operational parameter with significant effects was determined to be column length, with increased column length resulting in higher $\mathrm{CO}_{2} \mathrm{DFs}$.

Following these $\mathrm{CO}_{2}$ tests, a single iodine scrubber test was performed deliberately at a condition indicated by the $\mathrm{CO}_{2}$ demonstration to result in poor column performance. This was intended to establish a lower performance bound for iodine removal by the aqueous scrubber. The result showed that even under the adverse operating conditions, an iodine DF of $>100$ could be achieved.

Finally, the aqueous scrubber and a AgZ polishing bed were integrated. This simple caustic scrubber system achieved an iodine DF of $>12,000$ for just the scrubber portion. Using this iodine DF, the iodine loading on the polishing bed was reduced by $99.993 \%$. The performance of that integrated system was compared to a system including only a AgZ sorbent bed. The system without the scrubber also showed iodine DFs $>3000$ until breakthrough was observed. The loading on the saturated portion of the bed

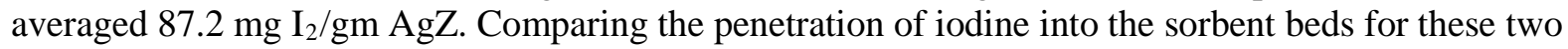
systems showed a marked difference; the penetration with the scrubber was only $0.65 \mathrm{~cm}$ at a maximum

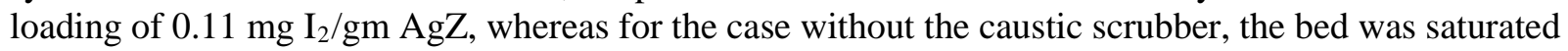
for the first $7 \mathrm{~cm}$ and breakthrough of the $13.3 \mathrm{~cm}$ bed occurred. 
This page is intentionally left blank. 


\section{CONTENTS}

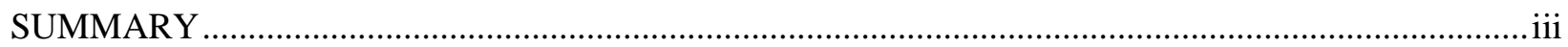

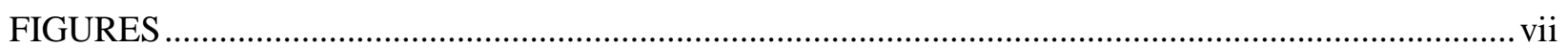

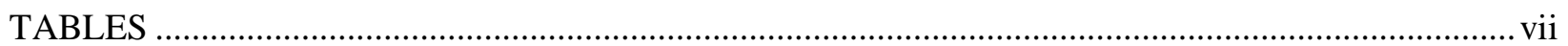

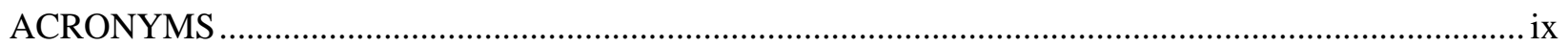

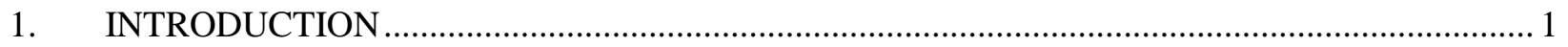

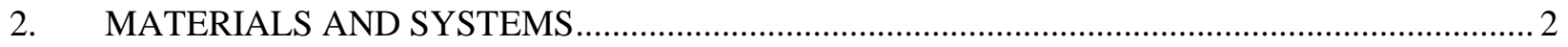

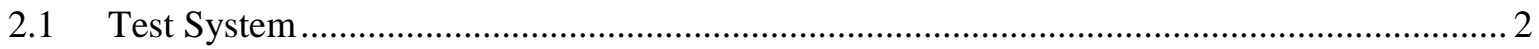

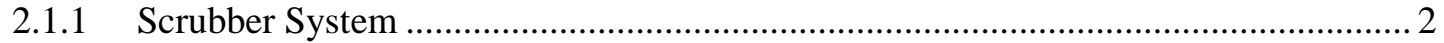

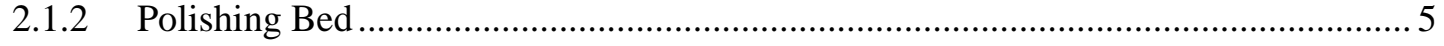

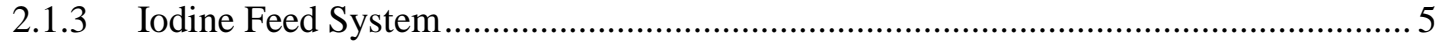

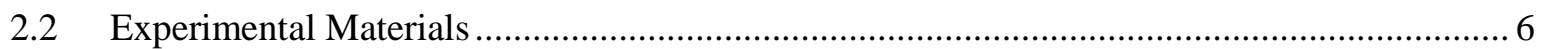

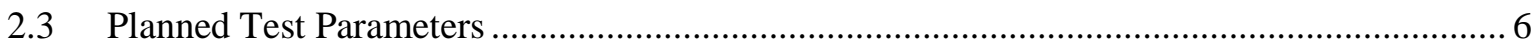

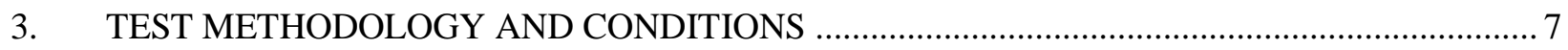

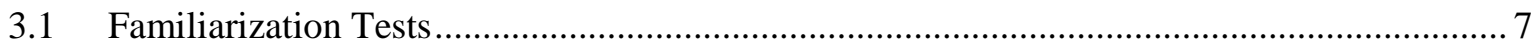

3.2 Phase 1 - Baseline Scrubber Performance ......................................................................... 8

3.3 Phase 2 - Iodine Capture from $\mathrm{CO}_{2}$-Free Air.............................................................. 9

3.4 Phase 3 - Combined Iodine Scrubber and Sorbent Bed Capture with Caustic Scrub

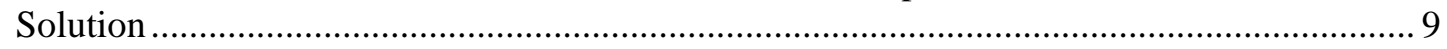

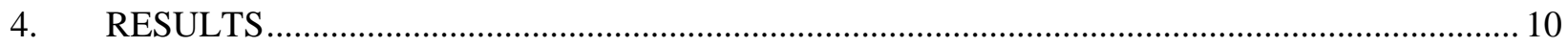

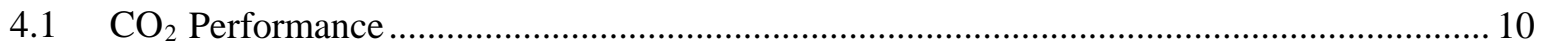

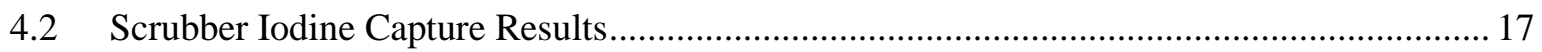

4.3 Combined Iodine Scrubber and Polishing Bed ................................................................ 18

4.3.1 Extended Scrubber Performance.......................................................................... 18

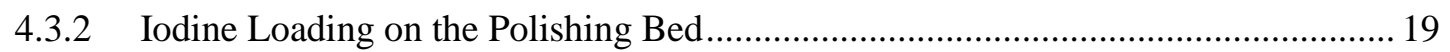

4.4 Iodine Loading on Solid Sorbent Bed without Scrubber .................................................... 20

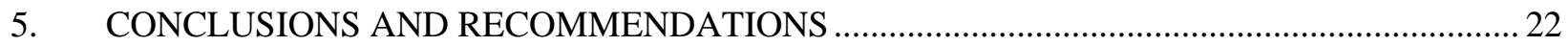

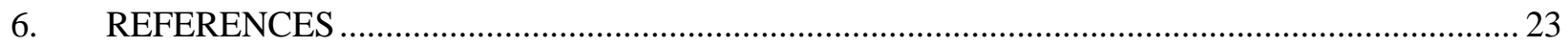


This page is intentionally left blank. 


\section{FIGURES}

Figure 1. Schematic of a combined scrubber and sorbent-based iodine capture test system....................... 3

Figure 2. Scrubber system as installed in the hood and configured with the $0.3 \mathrm{~m}$ scrubbing

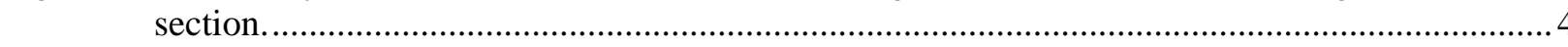
3

Figure 3. Scrubber system as installed in hood and configured with the $0.6 \mathrm{~m}$ scrubbing section............... 5

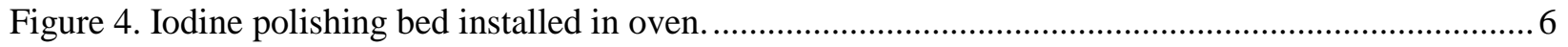

Figure 5. $\mathrm{CO}_{2} \mathrm{DF}$ as a function of packing length and scrub liquid recirculation rate............................ 13

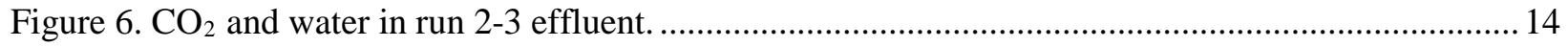

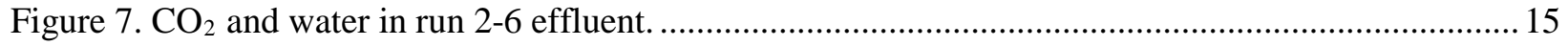

Figure 8. Calculated and analytically measured iodine concentration in the scrubber bottoms tank for the integrated iodine scrubber and polishing bed test. .................................................... 19

Figure 9. Iodine loading profile in the iodine polishing bed with the caustic scrubber off-line.................21

\section{TABLES}

Table 1. Phase 1 tests of scrubber to establish $\mathrm{CO}_{2}$ absorption efficiency and baseline parameters............ 8

Table 2. Phase 2 tests of scrubber with iodine to establish absorption efficiency without competing $\mathrm{CO}_{2}$ absorption.

Table 3. Phase 1 tests of scrubber to establish $\mathrm{CO}_{2}$ absorption efficiency and baseline parameters. (Using $\mathrm{CO}_{2}$ readings directly from $\mathrm{LI}-\mathrm{COR}^{\circledR}$.)

Table 4. Phase 1 tests of scrubber to establish $\mathrm{CO}_{2}$ absorption efficiency and baseline parameters. (LI-COR ${ }^{\circledR}$ effluent reading adjusted for baseline shift.)

Table 5. $\mathrm{CO}_{2}$ scrubbing efficiency as a function of packing length and scrub liquid recirculation rate

Table 6. Phase 2 tests of scrubber to establish $\mathrm{CO}_{2}$ absorption efficiency (DF) and baseline parameters using low scrubber recirculation rates.

Table 7. Phase 2 tests of scrubber to establish $\mathrm{CO}_{2}$ absorption efficiency (effluent concentration) and baseline parameters using low scrubber recirculation rates.

Table 8. Examination of the impact of variation in run 2-3 DF on effects analysis of independent variables

Table 9. Examination of the impact of variation in run 2-3 effluent concentration on effects analysis of independent variables.

Table 10. Comparison of cumulative iodine fed to scrubber and iodine accumulation in scrubber bottoms tank.

Table 11. Iodine loading on iodine polishing bed segments.

Table 12. Data obtained from iodine effluent sampler following iodine polishing bed without leading caustic scrubber.

Table 13. Iodine loading on iodine polishing bed segments without leading caustic scrubber. 
This page is intentionally left blank. 


\section{ACRONYMS}

$\begin{array}{ll}\mathrm{AgZ} & \text { silver-exchanged mordenite } \\ \mathrm{Ag}^{0} \mathrm{Z} & \text { hydrogen reduced silver-exchanged mordenite } \\ \text { DF } & \text { decontamination factor } \\ \text { DOG } & \text { dissolver off-gas } \\ \text { ICP/MS } & \text { inductively coupled plasma/mass spectrometry } \\ \text { L/G } & \text { liquid-to-gas mass ratio } \\ \text { ORNL } & \text { Oak Ridge National Laboratory } \\ \text { UNF } & \text { used nuclear fuel } \\ \text { VOG } & \text { vessel off-gas }\end{array}$


This page is intentionally left blank. 


\section{TESTING OF AN INTEGRATED IODINE SCRUBBER AND POLISHING BED SYSTEM}

\section{INTRODUCTION}

In 2016 an initial engineering evaluation and design of the off-gas abatement systems required for a hypothetical $1000 \mathrm{t} / \mathrm{yr}$ used nuclear fuel (UNF) reprocessing facility treating $5 \mathrm{yr}$-cooled, $60 \mathrm{GWd} / \mathrm{tIHM}$ UNF was completed. This study built upon a series of case studies that addressed various reprocessing options for the processing of UNF. The engineering design, while somewhat notional since this effort is not tied to a specific UNF processing facility, was intended to help all those involved with UNF reprocessing grasp the complexity and sizes of the required systems.

In this study two types of silver-based iodine sorbents were considered. The first was a silver-exchanged mordenite (AgZ), and the second was a silver-functionalized silica aerogel. In the initial design of the dissolver off-gas (DOG) iodine beds, the sorbent capacity was assumed to be $40 \mathrm{mg} \mathrm{I} / \mathrm{g}$ sorbent. This equates to about a 35\% silver utilization assuming the formation of AgI. The total iodine released from the fuel, used as input for the design of the DOG system, was $1.635 \mathrm{~kg} /$ day. Tramp halogens increased this to $\sim 5.1 \mathrm{~kg} /$ day on an iodine equivalent basis. The daily consumption of iodine sorbent was $\sim 166 \mathrm{~kg}$ (including the mass transfer zones that have lower iodine loading). The iodine capture system was designed to utilize five beds in parallel. In this design each bed was $\sim 1 \mathrm{~m}$ in diameter and $1.5 \mathrm{~m}$ long. This design allowed the beds to remain on line for 20 days, but at that point all five beds would need to be replaced, resulting in considerable material handling.

The alternative iodine sorbent, silver aerogel, was also considered. This sorbent is less dense than the mordenite material but contains four to five times more silver (the primary iodine reactant). This combination means that the number of columns could be reduced or the time between column change-out could be lengthened by roughly a factor of two.

It has been proposed that the bed life could be extended significantly, and the number of parallel beds reduced (potentially to a single bed) if an iodine scrubber preceded the solid sorbent iodine capture beds. Assuming that a decontamination factor (DF) of 10 to 20 could be achieved in the scrubber, then a single sorbent bed could remain on line 40 to 80 days between change replacements. This would reduce the sorbent usage by 90 to $95 \%$ and significantly reduce the associated frequent remote handing of the iodine filter beds. It is recognized that processing of the scrubber bottoms will be required but the processing of liquid streams it believed to be simpler in a remote environment than the handling of solids.

Wet scrubbing has been studied and used for capturing iodine in UNF reprocessing (Jubin et al. 2013, Soelberg et al. 2013). Previous studies determined that high iodine DFs (up to about 3,000) were needed for DOG systems to meet US regulatory requirements (Jubin et al. 2012) and that wet scrubbing alone was not likely to achieve such high efficiencies. Recent research has focused on chemisorption of iodine using solid silver sorbents, as summarized above. Following the engineering evaluation performed in 2016, which described the potential magnitude of the solid sorbent capture system for all the iodine (and other co-sorbing halogens in the off-gas), it was proposed that an integrated iodine capture system including wet scrubbing to capture the bulk of the iodine, followed by polishing using silver sorbents, could address the potential materials handling issue posed by a solid sorbent based system.

In early FY 2018 a relatively simple test bed was proposed in which the performance of an iodine scrubber system could be evaluated, and an extensive test plan (Jubin 2017) was developed to evaluate the test bed scrubber and demonstrate the performance of the combined scrubber coupled with a silver-based solid sorbent bed for final iodine polishing. This detailed test plan laid out a number of structured sets of proposed experiments that would likely take 1.5 to 2 years to complete. 
This report describes the test bed and the initial familiarization tests that were conducted to define the basic operating envelope of the scrubber system. This will be followed by a selected series of tests from the test plan to define the scrubber system's DF response for both $\mathrm{CO}_{2}$ and iodine as a function of process variables. The use of $\mathrm{CO}_{2}$ in the initial tests provides two benefits. The first is that the performance of the scrubber column can be observed in real time using relatively inexpensive on-line instrumentation. The second, reason is that there will be ${ }^{14} \mathrm{C}$ as ${ }^{14} \mathrm{CO}_{2}$ in the DOG stream that will be scrubbed along with the target iodine and thus the overall capture performance is also of interest. The series of tests described here culminated with an extended demonstration of the impact of coupling the scrubber with the solid sorbent iodine capture/polishing bed.

The overall goals of the iodine tests that were conducted were to demonstrate an iodine DF of 10 to 50 in the scrubber and to identify a range of operating conditions suitable for testing the scrubber with a silverbased solid sorbent bed to achieve an overall iodine DF of $>3000$. If successful, this would then offer the potential to extend the life of the iodine sorbent columns by 10 to 25 times and/or allow the use of fewer sorbent beds.

\section{MATERIALS AND SYSTEMS}

\subsection{Test System}

Due to the corrosive nature of iodine, especially in the presence of water, the materials of construction for the system were carefully selected to minimize iodine loss to system components and piping.

\subsubsection{Scrubber System}

The scrubber test system used in these tests was a three-liter laboratory scrubber (ChemGlass model CG1830-10)). The scrubber system was installed in the south hood of Lab 38 in Building 4505.

The maximum gas rate based on the manufacturing literature is 3 liter/min (ChemGlass 2018) at the maximum liquid pumping rate. The supplied KL Lab PTFE diaphragm pump (ChemGlass part number CG-1171-20) specification indicated a maximum liquid rate of $3 \mathrm{l} / \mathrm{min}$. The scrubber unit is supplied with a single 12 inch $(30 \mathrm{~cm}$ ) long absorber section containing $8 \times 8 \mathrm{~mm}$ glass raschig rings. A second scrubber section was also procured to allow the scrubber length to be increased to $60 \mathrm{~cm}$ for specific tests. Figure 1 is a schematic of the test system as configured for the scrubber performance tests to be conducted with both $\mathrm{CO}_{2}$ and an iodine-laden gas stream. The scrubber unit with the $0.3 \mathrm{~m}$ and $0.6 \mathrm{~m}$ scrubbing sections installed in its testing location is shown in Figures 2 and 3 respectively. When required, the scrubber solution could be heated by using two heat exchangers (Graham condensers) installed on the recirculation loop. The temperature was controlled with VWR recirculating water baths to supply the heat transfer medium to the heaters.

During the course of the initial operational testing of the scrubber unit, the recirculation pump did not perform as specified and was replaced with a Micropump GJ-N23.JF1S, capable of delivering 23-2,300 $\mathrm{mL} / \mathrm{min}$.

A LI-COR model LI-850 $\mathrm{CO}_{2} / \mathrm{H}_{2} \mathrm{O}$ gas analyzer was installed on the scrubber effluent line with valving provision to allow periodic sampling of the feed gas. This instrument provides near-real-time analysis for both $\mathrm{CO}_{2}$ and $\mathrm{H}_{2} \mathrm{O}$. The $\mathrm{CO}_{2}$ measurement range is $0-20,000 \mathrm{ppm}$ with an accuracy of $1.5 \%$ of reading. To prevent $\mathrm{NaOH}$ from contacting the LI-COR ${ }^{\circledR}$ analyzer during the $\mathrm{CO}_{2}$ testing phase, the scrubber effluent was routed through a downdraft condenser operated at $18^{\circ} \mathrm{C}$ to condense excess moisture, with the condensate dropping into a collection pot. The condenser was followed by an entrained liquid knock-out pot consisting of a glass tube that drained to a large-volume collection bottle. 


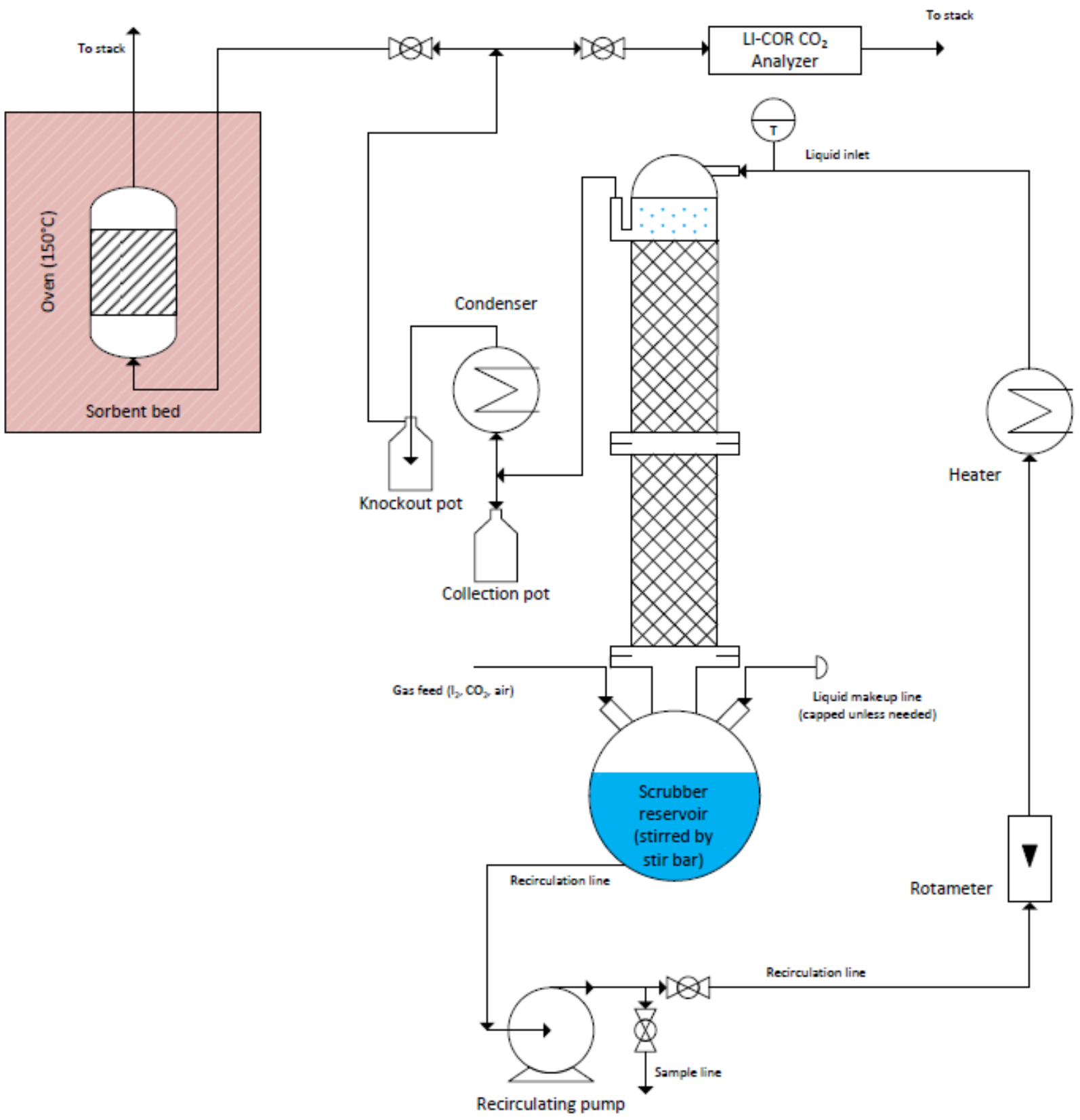

Figure 1. Schematic of a combined scrubber and sorbent-based iodine capture test system. (Note that the solids recovery system from the recirculation tank is not shown.) 


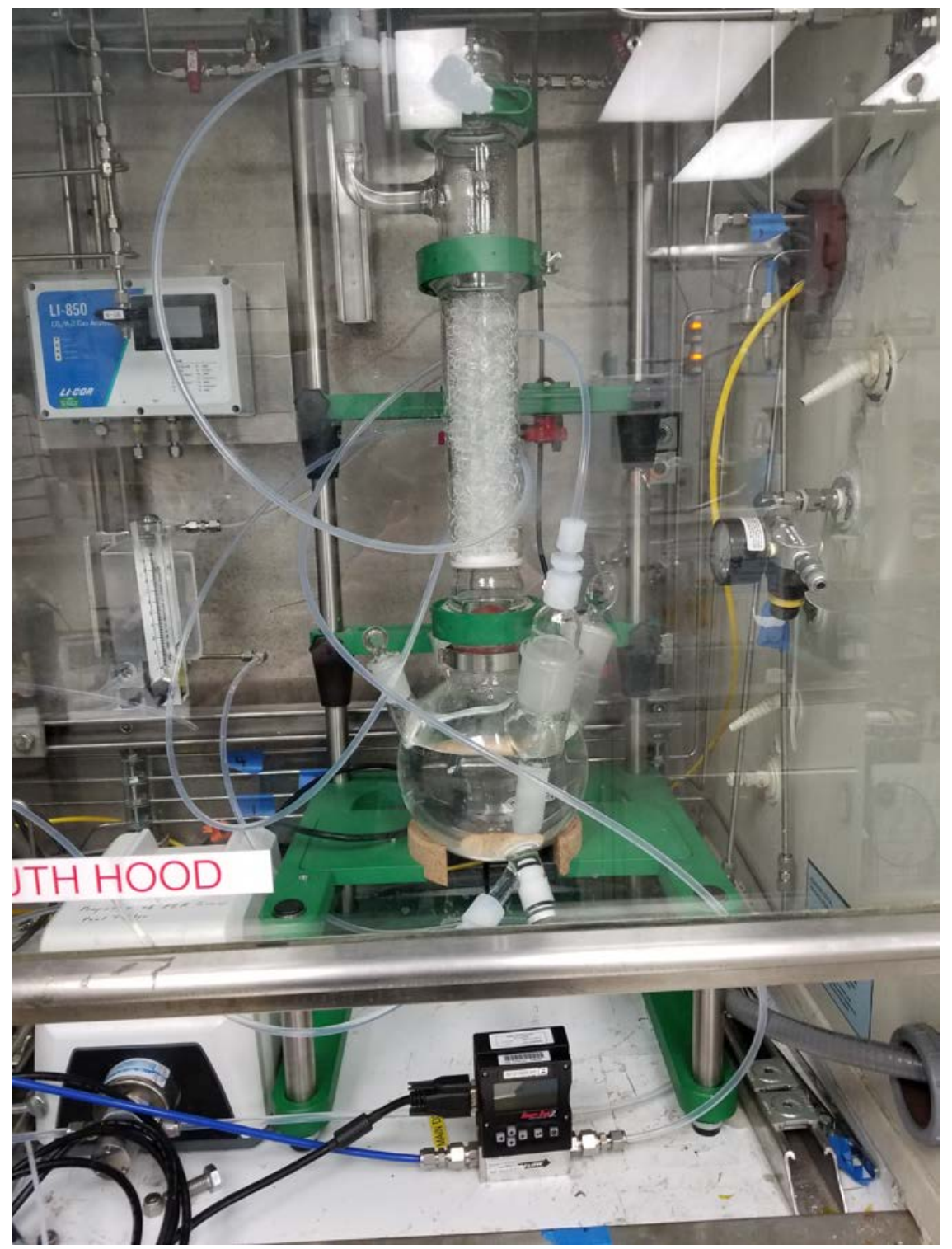

Figure 2. Scrubber system as installed in the hood and configured with the $0.3 \mathrm{~m}$ scrubbing section. 


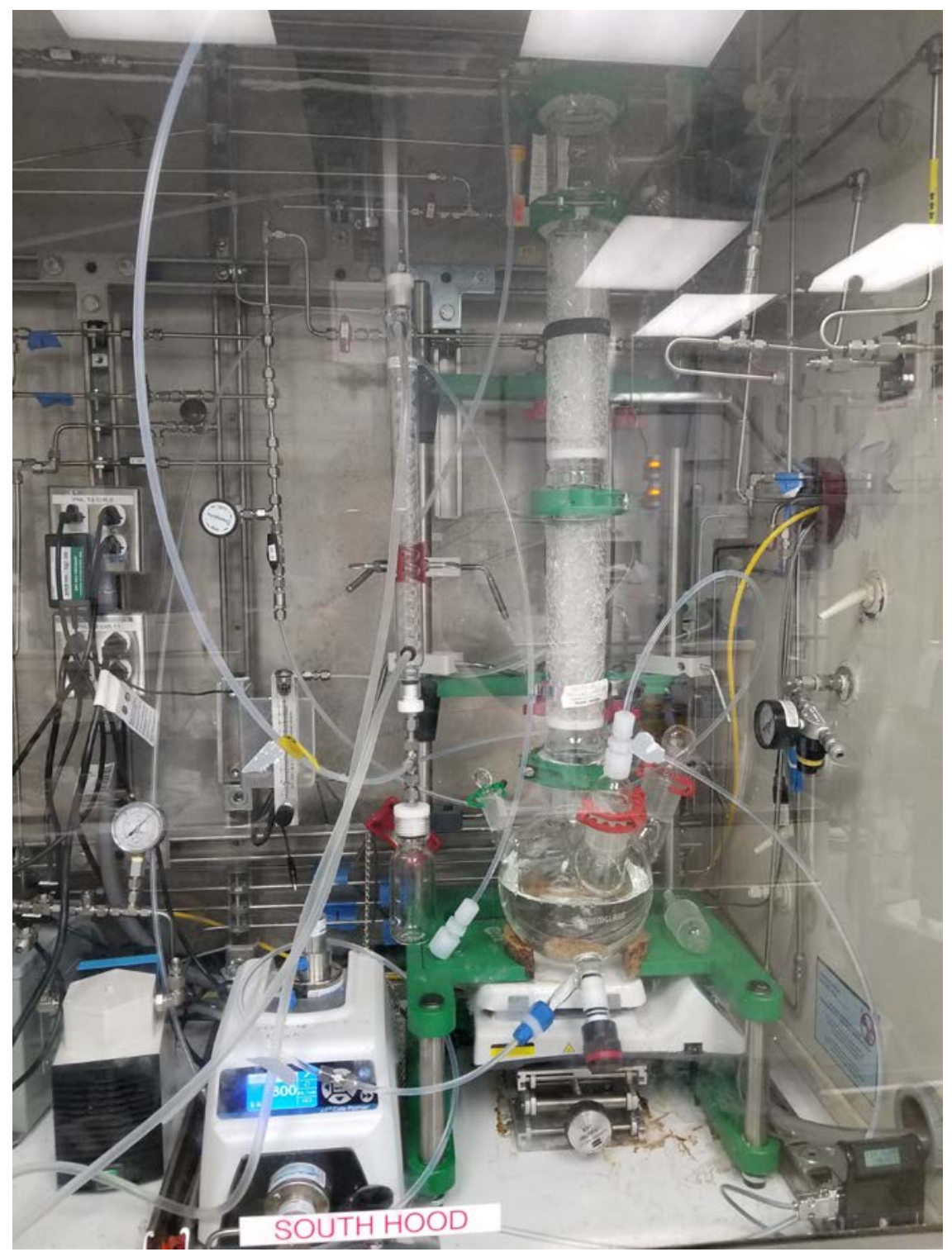

Figure 3. Scrubber system as installed in hood and configured with the $0.6 \mathrm{~m}$ scrubbing section.

\subsubsection{Polishing Bed}

The iodine polishing bed system consisted of a single deep bed contained within glass columns (internal diameter $=2.73 \mathrm{~cm}$ ). Figure 4 shows the polishing bed located in an oven. The glass column was filled with $71.12 \mathrm{~g}$ of $\mathrm{Ag}^{0} \mathrm{Z}$ for the integrated scrubber/polishing bed test, resulting in a bed depth of $13.6 \mathrm{~cm}$. The same glass column was used to contain the AgZ sorbent bed used for performance comparison with the integrated scrubber polishing bed and was filled with $71.27 \mathrm{~g}$ of $\mathrm{Ag}^{0} \mathrm{Z}$, resulting in a similar bed depth.

\subsection{3 lodine Feed System}

The iodine-laden gas stream was generated from an in-house design described in detail by Jubin (2011). This system relies on the sublimation of iodine crystals. By passing dry air through a temperaturecontrolled bed of iodine crystals, a stream of air saturated with elemental iodine at the column temperature can be generated. This saturated stream of iodine can be diluted with an air stream to produce the desired iodine concentration in a feed gas blend. 


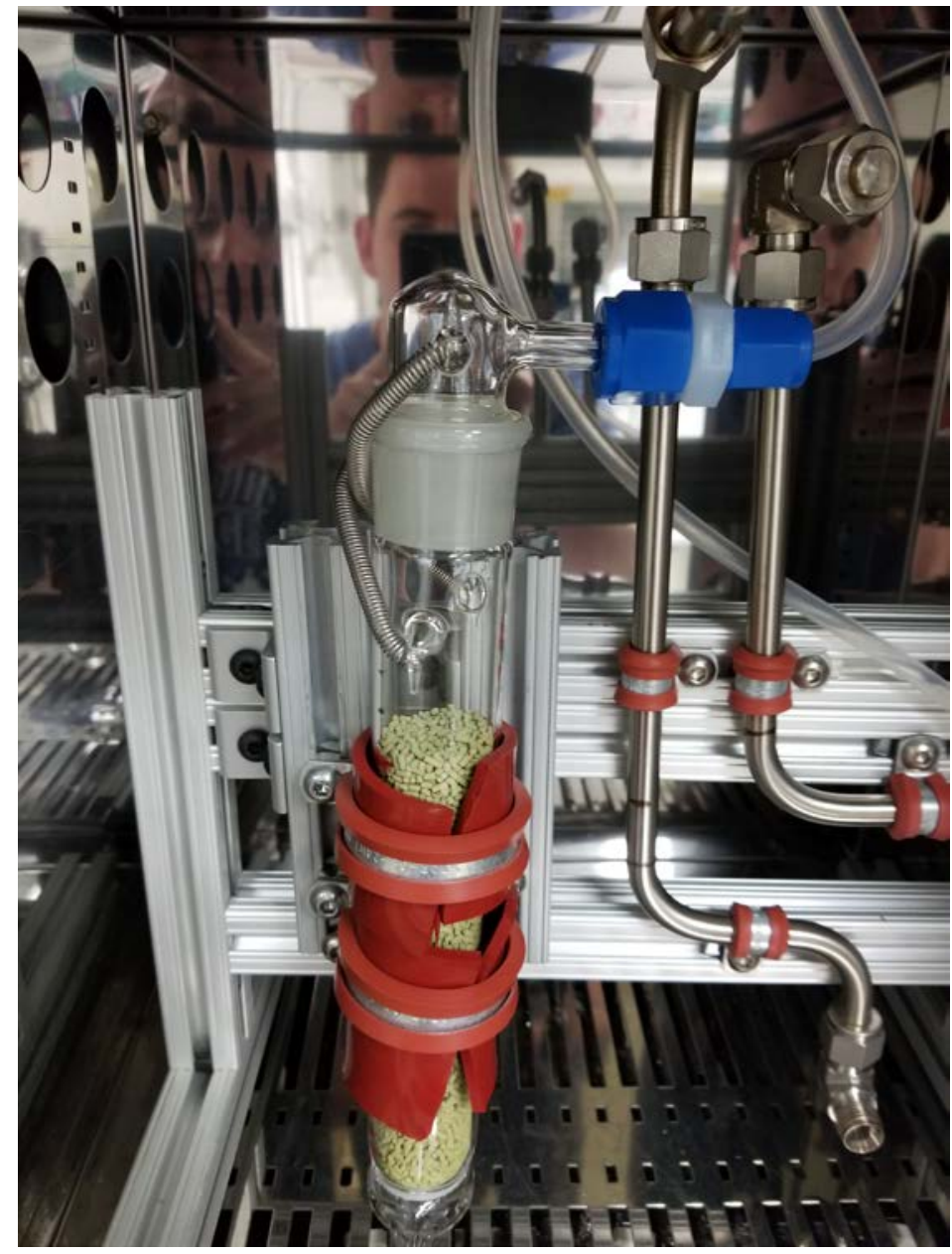

Figure 4. Iodine polishing bed installed in oven.

\subsection{Experimental Materials}

Reagent-grade $1 \mathrm{~N} \mathrm{NaOH}$ was procured from Fischer Scientific Company. Solutions of $0.1 \mathrm{~N} \mathrm{NaOH}$ were obtained by mixing this stock solution with distilled water.

Silver mordenite was obtained from Molecular Products in an engineered pelletized form (Ionex-Type Ag 900 E16). It contains $9.4 \mathrm{wt} \%$ silver and has a $0.16 \mathrm{~cm}$ pellet diameter. Prior to use in testing, the sorbent material was reduced by exposure to a $4 \% \mathrm{H}_{2}$ blend in argon at $270^{\circ} \mathrm{C}$ for 10 days. After reduction, the material was stored under argon to limit oxidation by air. Details of this procedure are provided by Anderson et al. (2012).

\subsection{Planned Test Parameters}

The design assumptions for this test system are described in the initial test plan (Jubin 2017). The initial phase of testing specified these key parameters:

- The feed stream will consist of $\mathrm{I}_{2}, \mathrm{CH}_{3} \mathrm{I}$ (as a surrogate for organic iodides), water vapor, and air containing $\mathrm{CO}_{2}$ at natural abundance. Concentrations of these species may vary for specific tests; some may not be present in all tests. (The FY2018 tests did not use $\mathrm{CH}_{3} \mathrm{I}$ )

- The concentration of $\mathrm{I}_{2}$ in the feed stream will be 10 to $40 \mathrm{ppm}$.

- The concentration of $\mathrm{CO}_{2}$ will nominally be 400 to 420 ppm. (FY2018 tests included 15,000 ppm) 
The process variables that were adjusted to evaluate the operating envelope of the laboratory-scale scrubber are listed here.

- Operating temperature range for the scrubber: ambient $\left(22-23^{\circ} \mathrm{C}\right)$ to $40^{\circ} \mathrm{C}$

- Packing length of glass raschig ring packing: 0.3 to $0.6 \mathrm{~m}$

- $\quad$ Target maximum gas rate: $2.0 \mathrm{l} / \mathrm{min}$

- Target liquid-to-gas (L/G) mass ratio: 1.0 to 10.0. (Operational performance tests described in Section 3.1 expanded the $\mathrm{L} / \mathrm{G}$ to 535 and 714.)

- Gas residence time in the scrubber: $30 \mathrm{~s}$ to $2 \mathrm{~min}$

- Initial $\mathrm{NaOH}$ scrub solution concentration: 0.1 to $1 \mathrm{M}$

The FY 2018 test series was designed to:

1. Gain familiarity with the overall performance of the scrubber system

2. Determine the equipment operating envelope and associated scrubbing performance

3. Select a set of operating parameters for use in conjunction with a silver-based solid sorbent bed for polishing purposes

4. Demonstrate extended operation of the scrubber system

5. Demonstrate extended operation while obtaining a DF of $>3000$ for the combined system

\section{TEST METHODOLOGY AND CONDITIONS}

The testing described here was broken down into a series of three test phases. The first phase of tests established the baseline performance of the scrubber column using the $\mathrm{CO}_{2}-\mathrm{air}-\mathrm{NaOH}$ system. The second phase of testing duplicated a selected test condition from Phase 1 with the $\mathrm{I}_{2}-\mathrm{CO}_{2}-$ free air- $\mathrm{NaOH}$ system. The third phase combined the scrubber and silver-based sorbent bed to demonstrate the combined system DF and relative iodine recovery in each portion of the system.

Initial tests were conducted in batch mode, as caustic concentrations decease slightly over time. Run durations were based on the time to achieve steady state conditions and the time required to deliver measurable amounts of analyte to the test system. Maximum duration of the run was then established by the available active reagent and the gas flow rate.

\subsection{Familiarization Tests}

A series of leak and performance tests were conducted to gain familiarity with the operation of the scrubber unit as it was installed in the hood. The initial objective was to operate with a L/G mass ratio of between 1 and 10. As was noted in the original test plan, there was a concern that this range would need to be adjusted based on operational constraints. At ambient conditions $\left(23^{\circ} \mathrm{C}, \sim 1 \mathrm{~atm}\right)$ and a gas rate of 2 $\mathrm{l} / \mathrm{min}$, the associated liquid rate would be 2.85 to $28.5 \mathrm{ml} / \mathrm{min}$. At these liquid rates there was the concern that the liquid flow could be insufficient to achieve adequate wetting of the column packing. Preliminary tests validated this concern. This portion of the original plan was adjusted accordingly.

A series of tests was then conducted to determine a suitable operating envelope for this column configuration. Based on visual observations, for a gas rate of $2 \mathrm{l} / \mathrm{min}$, adequate wetting of the column occurred with a liquid recycle rate of $0.5 \mathrm{l} / \mathrm{m}$ (L/G of 209). For the same gas rate, the column consistently flooded at a liquid rate of $1 \mathrm{l} / \mathrm{min}$ (L/G of 419). Flooding also occurred intermittently at a liquid recycle rate of $0.9 \mathrm{l} / \mathrm{min}$ ( $\mathrm{L} / \mathrm{G}$ of 377 ). Based on this data a fairly narrow operating range for the liquid recycle rate, 0.6 to $0.8 \mathrm{l} / \mathrm{min}$, was selected for future tests of the system. 
Gas rates ranging from $\sim 0.7$ to $\sim 1.4 \mathrm{l} / \mathrm{min}$ were then selected to yield $\mathrm{L} / \mathrm{G}$ of either 535 or 714 .

Familiarization tests with the LI-COR ${ }^{\circledR} \mathrm{CO}_{2}$ analyzer identified significant variation in the $\mathrm{CO}_{2}$ content of the plant air after passing through the drying system in the lab. Day-to-day variations of over $100 \mathrm{ppm}$ were observed most likely due to the drying agents used within the laboratory to pretreat the plant air, leading to the decision to generate well-controlled $\mathrm{CO}_{2}$-bearing gas blends.

\subsection{Phase 1 - Baseline Scrubber Performance}

A structured set of experiments was conducted using a modified version of Table 3 from the original test plan to account for the actual wetting and flooding limitations of the system. The feed gas selected was a $\mathrm{CO}_{2}$ span gas containing $1.5 \% \mathrm{CO}_{2}$. For each test the scrubber was charged with 1.5 liters of fresh $\mathrm{NaOH}$ at the specified concentration for the specific test. Once a steady scrubber effluent $\mathrm{CO}_{2}$ concentration was measured (using the LI-COR ${ }^{\circledR}$ gas analyzer) steady state operation was considered to have begun, and the condition was held for 30 to 60 minutes before terminating the run and sampling the scrubber bottoms tank. The time-averaged $\mathrm{CO}_{2}$ in the scrubber effluent stream during the steady state period was used to calculate the DF for that test.

The modified test matrix is shown in Table 1 . The fixed variables were column length and $\mathrm{CO}_{2}$ inlet concentration. The following data were collected:

- $\mathrm{CO}_{2}$ concentration in inlet and effluent. Inlet concentration was determined at the start and end of each run via the LI-COR. The effluent concentration was measured continuously during the run using the LI-COR ${ }^{\circledR}$.

- Final carbonate and caustic concentrations in scrubber bottoms. The initial plan was to sample for carbonate and $\mathrm{NaOH}$ concentration in the scrubber bottoms during each run at periodic time increments. However, steady state was achieved in under $30 \mathrm{~min}$, so extended operations were unnecessary. As a result, the scrubber bottoms tank was sampled only at the end of each individual test.

The primary objective of this test phase was to quickly establish the general performance characteristics of the test system using the online instrumentation and thus avoid the delays inherent in other wet chemistry or neutron activation analyses associated with iodine-containing samples. As discussed in Section 4.1, the $\mathrm{CO}_{2}$ scrubbing performance was excellent to the point that little could be concluded about the effects of individual process parameters. In an attempt to provide additional, or at least some, insight into the operating parameters, additional tests were performed at less than optimal conditions.

Table 1. Phase 1 tests of scrubber to establish $\mathrm{CO}_{2}$ absorption efficiency and baseline parameters.

\begin{tabular}{|c|c|c|c|c|c|c|c|}
\hline \multirow{3}{*}{ Run No. } & Temp. & Liquid rate & $\begin{array}{c}\text { Packing } \\
\text { length }\end{array}$ & L/G mass ratio & $\begin{array}{c}\text { Caustic } \\
\text { conc. }\end{array}$ & Dummy & Dummy \\
\cline { 2 - 7 } & $+=40^{\circ} \mathrm{C}$ & $+=0.8 \mathrm{l} / \mathrm{min}$ & $+=0.6 \mathrm{~m}$ & $+=714$ & $+=1.0 \mathrm{M}$ & Factor 1 & Factor 2 \\
$-=25^{\circ} \mathrm{C}$ & $-=0.6 \mathrm{l} / \mathrm{min}$ & $-=0.3 \mathrm{~m}$ & $-=535$ & $-=0.1 \mathrm{M}$ & & \\
\hline $1-1$ & - & - & - & - & + & + & + \\
\hline $1-2$ & + & - & - & + & + & - & - \\
\hline $1-3$ & - & + & - & + & - & + & - \\
\hline $1-4$ & + & + & - & - & - & - & + \\
\hline $1-5$ & - & - & + & + & - & - & + \\
\hline $1-6$ & + & - & + & - & - & + & - \\
\hline $1-7$ & - & + & + & - & + & - & - \\
\hline $1-8$ & + & + & + & + & + & + & + \\
\hline
\end{tabular}

Note: Dummy Factors column may be used to estimate the experimental error associated with the results of the individual runs. 


\subsection{Phase 2 - lodine Capture from $\mathrm{CO}_{2}$-Free Air}

The planned Phase 2 tests were designed to be conducted with elemental iodine in a $\mathrm{CO}_{2}$-free air stream. Initial operating parameters for the column $\mathrm{L} / \mathrm{G}$ ratio and caustic concentration were to be based on the Phase 1 tests. Water could be added to the system to maintain a near constant level in the bottoms tank if necessary.

This was to have been a simple two-factor experimental design. Variables were to be tested through use of a structured set of experiments as shown in Table 2 and focused on the effects of iodine inlet concentration and column packing length. All other factors were to have been held constant.

The test plan called for the following data to be collected:

- Iodine concentration in inlet and effluent using caustic scrub followed by inductively coupled plasma/mass spectrometry (ICP/MS) analysis of the scrub solution.

- Iodine, carbonate, and $\mathrm{NaOH}$ concentrations in the scrubber bottoms, sampled periodically during run and at the end.

- However, as discussed in Sections 4.1, and 4.2, the test system proved to be far more efficient than originally expected, so this phase of the testing was reduced to a single attempt to provide a lower "bounding” performance determination.

Table 2. Phase 2 tests of scrubber with iodine to establish absorption efficiency without competing $\mathrm{CO}_{2}$ absorption.

\begin{tabular}{|c|c|c|}
\hline \multirow{2}{*}{ Run No. } & $\begin{array}{c}\text { Iodine feed } \\
\text { concentration } \\
{\left[\mathrm{I}_{2}\right]}\end{array}$ & Packing length \\
\cline { 2 - 3 } & $\begin{array}{c}+=40 \mathrm{ppm} \\
-=10 \mathrm{ppm}\end{array}$ & $\begin{array}{c}+=0.6 \mathrm{~m} \\
-=0.3 \mathrm{~m}\end{array}$ \\
\hline $2-1$ & - & - \\
\hline $2-2$ & + & - \\
\hline $2-3$ & - & + \\
\hline $2-4$ & + & + \\
\hline
\end{tabular}

\subsection{Phase 3 - Combined lodine Scrubber and Sorbent Bed Capture with Caustic Scrub Solution}

The third phase of testing utilized a selected condition for the scrubber operation based on Phase 1 and 2 tests. The effluent from the scrubber was fed through a heat exchanger and directly into a segmented $13 \mathrm{~cm}$ deep bed of hydrogen-reduced silver mordenite $\left(\mathrm{Ag}^{0} \mathrm{Z}\right)$ operated at $150^{\circ} \mathrm{C}$. The target iodine concentration was based on a theoretical iodine volatilization rate of $0.421 \mathrm{mg} / \mathrm{min}$, which would have resulted in a stream containing $40 \mathrm{ppm} \mathrm{I}_{2}$. However, this rate was validated experimentally by diverting the $\mathrm{I}_{2}$ stream into a $\mathrm{NaOH}$ scrubber for a known period of time and determining the resultant $\mathrm{I}_{2}$ concentration by ICP-MS. The experimentally determined iodine delivery rate was $0.336 \mathrm{mg} / \mathrm{min}$, corresponding to $32 \mathrm{ppmv}$ in the gas stream. The $\mathrm{NaOH}$ concentration was $1 \mathrm{M}$. The scrubber conditions were set to provide an $\mathrm{L} / \mathrm{G}$ of 700 , a liquid rate of $0.8 \mathrm{l} / \mathrm{min}$, and an operating temperature of $25^{\circ} \mathrm{C}$ using a packing length of $0.6 \mathrm{~m}$.

The feed gas was passed into the scrubber, then was passed up through a condenser and chilled to $18^{\circ} \mathrm{C}$. The liquid in the condenser was collected in an attached knockout pot. After cooling, the gas was passed into the oven and through the $\mathrm{Ag}^{0} \mathrm{Z}$ column, then finally out of the sorbent bed. 
During testing, samples of the liquid were pulled by pumping liquid through a tee in the line prior to liquid introduction to the top of the column, allowing testing to continue without interruption of gas flow. The system was charged with $500 \mathrm{~mL}$ of $1 \mathrm{M} \mathrm{NaOH}$ halfway through the test to compensate for the volume loss due to sampling, evaporation losses, and an observed small leak. The scrubber liquid was sampled once daily in $\sim 35 \mathrm{~mL}$ aliquots. Two days into testing, the liquid in the bottoms tank had become noticeably discolored with a yellow tinge.

This test ran for 10.14 days. Upon completion of testing, the scrubber solution was pulled from the system, the volume was measured, and the solution was retained for analysis. Samples of the liquid were taken from various places in the bottoms tank (including near the liquid pump inlet, at the top of the liquid, at the bottom of the tank, and from the solution opposite the liquid pump inlet).

The scrubber bottoms were analyzed by ICP-MS to determine iodine content in the scrubber over the 10day test duration.

The solid sorbent bed containing the iodine-loaded AgZ was sampled by vacuum collecting discrete portions beginning at the top of the bed. The bed was removed in portions or segments that were nominally $1-3 \mathrm{~cm}$ in length. The segments recovered from the bed had an average weight of 3-12 $\mathrm{g}$ (the leading portion of the bed was sampled in smaller increments as compared to the trailing portion of the bed). Each of these bed segments was individually mixed by hand in glass containers. Small sub-samples of roughly $0.2 \mathrm{~g}$ were taken from each of the segments and sent for neutron activation analysis at ORNL's High Flux Isotope Reactor to determine total iodine content.

Key data resulting from this test were the scrubber iodine DF and the overall system iodine DF. It is recognized that the determination of the final effluent iodine concentration from the combined system may approach detection limits, which may limit the quantification of this value.

Due to the potential limitations in determining the overall system DF, a separate test was conducted to compare the combined system performance to the performance of an independent AgZ sorbent bed under similar conditions but without the scrubber. The comparison of the AgZ loadings for these two tests, coupled with the analysis of the scrubber bottoms were intended to provide a demonstration of the potential benefit of the coupled system towards extending the service life of the solid sorbent iodine capture beds.

\section{RESULTS}

\section{1 $\mathrm{CO}_{2}$ Performance}

Table 3 summarizes the DF results from the structured $\mathrm{CO}_{2}$ performance matrix. In all cases the $\mathrm{CO}_{2} \mathrm{DF}$ exceeded 650. These results are based on the recorded $\mathrm{CO}_{2}$ values taken directly from the LI-COR ${ }^{\circledR} \mathrm{CO}_{2}$ analyzer. These effluent values ranged from 11 to $22.9 \mathrm{ppm}$ across the set of eight runs. The greatest effects of the system variables on the $\mathrm{CO}_{2} \mathrm{DF}$ arose from the scrubber temperature, packing length, and liquid rate. The increase in scrubber temperature or liquid rate had adverse effects on the system DF, and the increase in scrubber length had a positive effect of about half the magnitude of the temperature effect. The adverse impact of increasing the liquid rate is unexpected, however, the result may be confounded by the inclusion of a related second independent, the L/G. The effects represented by the Dummy Factors are indicative that the potential interaction effects would be comparable in magnitude to those of the packing length and liquid rate in this operating regime. 
Table 3. Phase 1 tests of scrubber to establish $\mathrm{CO}_{2}$ absorption efficiency and baseline parameters. (Using $\mathrm{CO}_{2}$ readings directly from LI-COR ${ }^{\circledR}$.)

\begin{tabular}{|c|c|c|c|c|c|c|c|c|c|}
\hline \multirow{2}{*}{$\begin{array}{l}\text { Run } \\
\text { No. }\end{array}$} & $\begin{array}{l}\text { Effluent } \\
\mathrm{CO}_{2}\end{array}$ & DF & Temp. & Liquid rate & $\begin{array}{c}\text { Packing } \\
\text { length }\end{array}$ & $\begin{array}{l}\mathrm{L} / \mathrm{G} \text { mass } \\
\text { ratio }\end{array}$ & $\begin{array}{c}\text { Caustic } \\
\text { conc. }\end{array}$ & \multirow{2}{*}{$\begin{array}{l}\text { Dummy } \\
\text { Factor } 1\end{array}$} & \multirow{2}{*}{$\begin{array}{l}\text { Dummy } \\
\text { Factor } 2\end{array}$} \\
\hline & $\begin{array}{l}\text { conc. } \\
\text { (ppm) }\end{array}$ & response & $\begin{array}{l}+=40^{\circ} \mathrm{C} \\
-=25^{\circ} \mathrm{C} \\
\end{array}$ & $\begin{array}{l}+=0.8 \mathrm{l} / \mathrm{min} \\
-=0.6 \mathrm{l} / \mathrm{min}\end{array}$ & $\begin{array}{l}+=0.6 \mathrm{~m} \\
-=0.3 \mathrm{~m}\end{array}$ & $\begin{array}{l}+=714 \\
-=535\end{array}$ & $\begin{array}{l}+=1.0 \mathrm{M} \\
-=0.1 \mathrm{M}\end{array}$ & & \\
\hline $1-1$ & 14.5 & 1076 & - & - & - & - & + & + & + \\
\hline $1-2$ & 22.5 & 694 & + & - & - & + & + & - & - \\
\hline $1-3$ & 22.9 & 682 & - & + & - & + & - & + & - \\
\hline $1-4$ & 22 & 709 & + & + & - & - & - & - & + \\
\hline $1-5$ & 11 & 1426 & - & - & + & + & - & - & + \\
\hline $1-6$ & 23 & 676 & + & - & + & - & - & + & - \\
\hline $1-7$ & 14 & 1121 & - & + & + & - & + & - & - \\
\hline $1-8$ & 23 & 676 & + & + & + & + &.+ & + & + \\
\hline$\Sigma+$ & & 7061 & 2755 & 3189 & 3900 & 3478 & 3567 & 3110 & 3887 \\
\hline$\Sigma-$ & & & 4306 & 3872 & 3161 & 3582 & 3493 & 3950 & 3174 \\
\hline$\Delta$ & & & -1550 & -683 & 738 & -104 & 74 & -840 & 713 \\
\hline Effect & & & -388 & -171 & 185 & -26 & 18 & -210 & 178 \\
\hline
\end{tabular}

During the course of this test series, some slight upward drift in the zero value of the LI-COR was noted when checks were performed with nitrogen. Table 4 attempts to account for this upward drift and effectively correct the effluent $\mathrm{CO}_{2}$ reading. Between several of the individual runs, zero values were not obtained and these were estimated based on the run sequence and the adjacent zero values. In addition, the corrected effluent $\mathrm{CO}_{2}$ concentration was limited to a lower value of $1 \mathrm{ppm}$. The resultant corrected values range from 1 to $14.5 \mathrm{ppm} \mathrm{CO} 2$ in the effluent. With the already low effluent values, this correction resulted in a significant increase in the overall DFs, which now range from 1400 to 15,000. The temperature and packing length again appeared to have the largest impact on DF. Increasing the packing length again appears to have improved the DF. However, the effect of increasing the operating temperature now appears to be the opposite of that observed using the uncorrected effluent concentrations (Table 3). The sequencing of individual runs was such that that the 4 runs at high temperature condition were run later in the test sequence. This meant that the instrument drift was the greatest at this point, the observed $\mathrm{CO}_{2}$ effluent concentrations required the greatest correction factors which in all cases resulted in large increases in the calculated $\mathrm{CO}_{2} \mathrm{DF}$ values. Thus, the impact of temperature in this test matrix was confounded due to the drift of the $\mathrm{CO}_{2}$ analyzer. The effects of variations in liquid rate, $\mathrm{L} / \mathrm{G}$, or caustic concentration over the ranges examined appear to have had minimal effects on the system $\mathrm{CO}_{2} \mathrm{DF}$. The two "dummy factors" again indicate that some process parameter interaction was occurring. Importantly, in either of the cases represented in Tables 3 and 4, it is clear that very high $\mathrm{CO}_{2}$ DFs are achievable.

While it is highly desirable in operations to have high DFs, as were observed in the execution of this test matrix, such values result in very low $\mathrm{CO}_{2}$ concentrations in the effluent. In this case, a shift of a few parts per million resulted in significant shifts in the apparent effects, as shown by a comparison of Tables 3 and 4. As noted in the familiarization tests, the $\mathrm{L} / \mathrm{G}$ ratio was increased to improve column wetting. It was believed that this increase likely resulted in a significant improvement in overall system performance. To evaluate that effect, a series of tests was conducted in which only the liquid rate was adjusted to determine its effect on the $\mathrm{CO}_{2} \mathrm{DF}$. The tests conditions were as follows.

$\begin{array}{ll}\mathrm{NaOH} & 1 \mathrm{~N} \\ \text { Temperature } & 23^{\circ} \mathrm{C} \text { (ambient) } \\ \text { Gas rate } & 1 \mathrm{l} / \mathrm{min} \\ \text { Gas composition } & 1.5 \% \mathrm{CO}_{2} \\ \text { Packing length } & 0.3 \text { and } 0.6 \mathrm{~m}\end{array}$

Initial liquid rate 0 to $0.6 \mathrm{l} / \mathrm{m}$ (or a $\mathrm{L} / \mathrm{G}$ of 84 to 503$)$

$\begin{array}{ll}\text { Gas composition } & 1.5 \% \mathrm{CO}_{2} \\ \text { Packing length } & 0.3 \text { and } 0.6 \mathrm{~m}\end{array}$ 
Table 4. Phase 1 tests of scrubber to establish $\mathrm{CO}_{2}$ absorption efficiency and baseline parameters. (LI-COR ${ }^{\circledR}$ effluent reading adjusted for baseline shift.)

\begin{tabular}{|c|c|c|c|c|c|c|c|c|c|c|c|}
\hline \multirow{2}{*}{$\begin{array}{l}\text { Run } \\
\text { No. }\end{array}$} & \multirow{2}{*}{$\begin{array}{c}\text { Zero } \\
\text { value } \\
\text { (sppm) }\end{array}$} & \multirow{2}{*}{$\begin{array}{c}\text { Selected } \\
\text { zero } \\
\text { value } \\
(\mathrm{ppm})\end{array}$} & \multirow{2}{*}{$\begin{array}{c}\text { Corrected } \\
\text { effluent } \\
\mathrm{CO}_{2} \text { conc. } \\
\text { (ppm) }\end{array}$} & \multirow{2}{*}{$\begin{array}{c}\mathrm{DF} \\
\text { response }\end{array}$} & Temp. & Liquid rate & \begin{tabular}{|c|} 
Packing \\
length
\end{tabular} & $\begin{array}{c}\mathrm{L} / \mathrm{G} \text { mass } \\
\text { ratio }\end{array}$ & \begin{tabular}{|c|} 
Caustic \\
conc.
\end{tabular} & \multirow{2}{*}{$\begin{array}{l}\text { Dummy } \\
\text { Factor } 1\end{array}$} & \multirow{2}{*}{$\begin{array}{l}\text { Dummy } \\
\text { Factor } 2\end{array}$} \\
\hline & & & & & $\begin{array}{l}+=40^{\circ} \mathrm{C} \\
-=25^{\circ} \mathrm{C}\end{array}$ & $\begin{array}{l}+=0.8 \mathrm{l} / \mathrm{min} \\
-=0.6 \mathrm{l} / \mathrm{min}\end{array}$ & $\begin{array}{l}+=0.6 \mathrm{~m} \\
-=0.3 \mathrm{~m}\end{array}$ & $\begin{array}{l}+=714 \\
-=535\end{array}$ & $\begin{array}{l}+=1.0 \mathrm{M} \\
-=0.1 \mathrm{M}\end{array}$ & & \\
\hline $1-1$ & $\mathrm{~N} / \mathrm{R}$ & $10^{\mathrm{a}}$ & 4.5 & 3467 & - & - & - & - & + & + & + \\
\hline $1-2$ & 20 & 20 & 2.5 & 6244 & + & - & - & + & + & - & - \\
\hline $1-3$ & 17 & 17 & 5.9 & 2648 & - & + & - & + & - & + & - \\
\hline $1-4$ & 17 & 17 & 5 & 3120 & + & + & - & - & - & - & + \\
\hline $1-5$ & 0 & 0 & 11 & 1426 & - & - & + & + & - & - & + \\
\hline $1-6$ & 22.5 & 22.5 & $1^{b}$ & 15550 & + & - & + & - & - & + & - \\
\hline $1-7$ & $\mathrm{~N} / \mathrm{R}$ & $5^{a}$ & 9 & 1744 & - & + & + & - & + & - & - \\
\hline $1-8$ & 23.5 & 23.5 & $1^{b}$ & 15550 & + & + & + & + & + & + & + \\
\hline$\Sigma+$ & & & & 49749 & 40464 & 23063 & 34270 & 25868 & 27005 & 37215 & 23563 \\
\hline$\Sigma-$ & & & & & 9285 & 26687 & 15479 & 23881 & 22744 & 12534 & 26187 \\
\hline$\Delta$ & & & & & 31179 & -3624 & 18791 & 1987 & 4261 & 24681 & -2624 \\
\hline Effect & & & & & 7795 & -906 & 4698 & 497 & 1065 & 6170 & -656 \\
\hline
\end{tabular}

${ }^{a}$ Estimated zero value.

${ }^{b}$ Limited to a lower limit of $1 \mathrm{ppm}$ following correction.

Note: Dummy Factors column may be used to estimate the experimental error or presence of interactions between the process variables associated with the results of the individual runs.

Once the $\mathrm{CO}_{2}$ concentration in the effluent had stabilized, the liquid rate was increased by $0.05 \mathrm{l} / \mathrm{min}$ and the $\mathrm{CO}_{2}$ effluent concentration was remeasured. The results of this test series are shown in Table 5 and Figure 5 . The results of this test indicated that for the $0.3 \mathrm{~m}$ column, relatively high efficiency was achieved at flow rates greater than $0.4 \mathrm{l} / \mathrm{min}$, but for the $0.6 \mathrm{~m}$ column, relatively high efficiency was achieved at flow rates greater than $0.1 \mathrm{l} / \mathrm{min}$. With good wetting (i.e., a recirculation rate of $>0.4 \mathrm{l} / \mathrm{min}$ and all other conditions as specified above), both column lengths showed comparable performance. It is also noted that even with no liquid recirculation through the scrubber, some $\mathrm{CO}_{2}$ removal occurs, simply due to the presence of the caustic in the scrubber bottoms tank.

Table 5. $\mathrm{CO}_{2}$ scrubbing efficiency as a function of packing length and scrub liquid recirculation rate

\begin{tabular}{|l|l|l|l|l|l|}
\hline $\begin{array}{c}\text { Liquid rate } \\
(\mathrm{mL} / \mathrm{min})\end{array}$ & $\mathrm{L} / \mathrm{G}$ & $\begin{array}{c}\text { Test } 1 \text { with } \\
0.6 \mathrm{~m} \text { packing } \\
{\left[\mathrm{CO}_{2}\right]}\end{array}$ & $\begin{array}{c}\text { Test 2 with } \\
0.3 \mathrm{~m} \text { packing } \\
{\left[\mathrm{CO}_{2}\right]}\end{array}$ & $\begin{array}{c}\text { Test } 1 \mathrm{DF} \\
(0.6 \text { m packing })\end{array}$ & $\begin{array}{c}\text { Test 2 DF } \\
(0.3 \text { m packing })\end{array}$ \\
\hline 0 & 0 & 4134 & 4093 & 3.7 & 3.7 \\
\hline 100 & 84 & 12.7 & 43.1 & 1191 & 352 \\
\hline 150 & 126 & 3.91 & 5.93 & 3883 & 2556 \\
\hline 200 & 168 & 3.45 & 5.54 & 4395 & 2737 \\
\hline 250 & 210 & 3.3 & 5.7 & 4601 & 2662 \\
\hline 300 & 252 & 3.08 & 4.79 & 4920 & 3165 \\
\hline 350 & 293 & 3.08 & 3.57 & 4925 & 4253 \\
\hline 400 & 335 & 3.07 & 3.04 & 4939 & 4990 \\
\hline 450 & 377 & 2.98 & 2.93 & 5094 & 5179 \\
\hline 500 & 419 & 2.84 & 2.82 & 5334 & 5380 \\
\hline 550 & 461 & 2.8 & 2.73 & 5426 & 5552 \\
\hline 600 & 503 & 2.7 & 2.62 & 5620 & 5782 \\
\hline
\end{tabular}




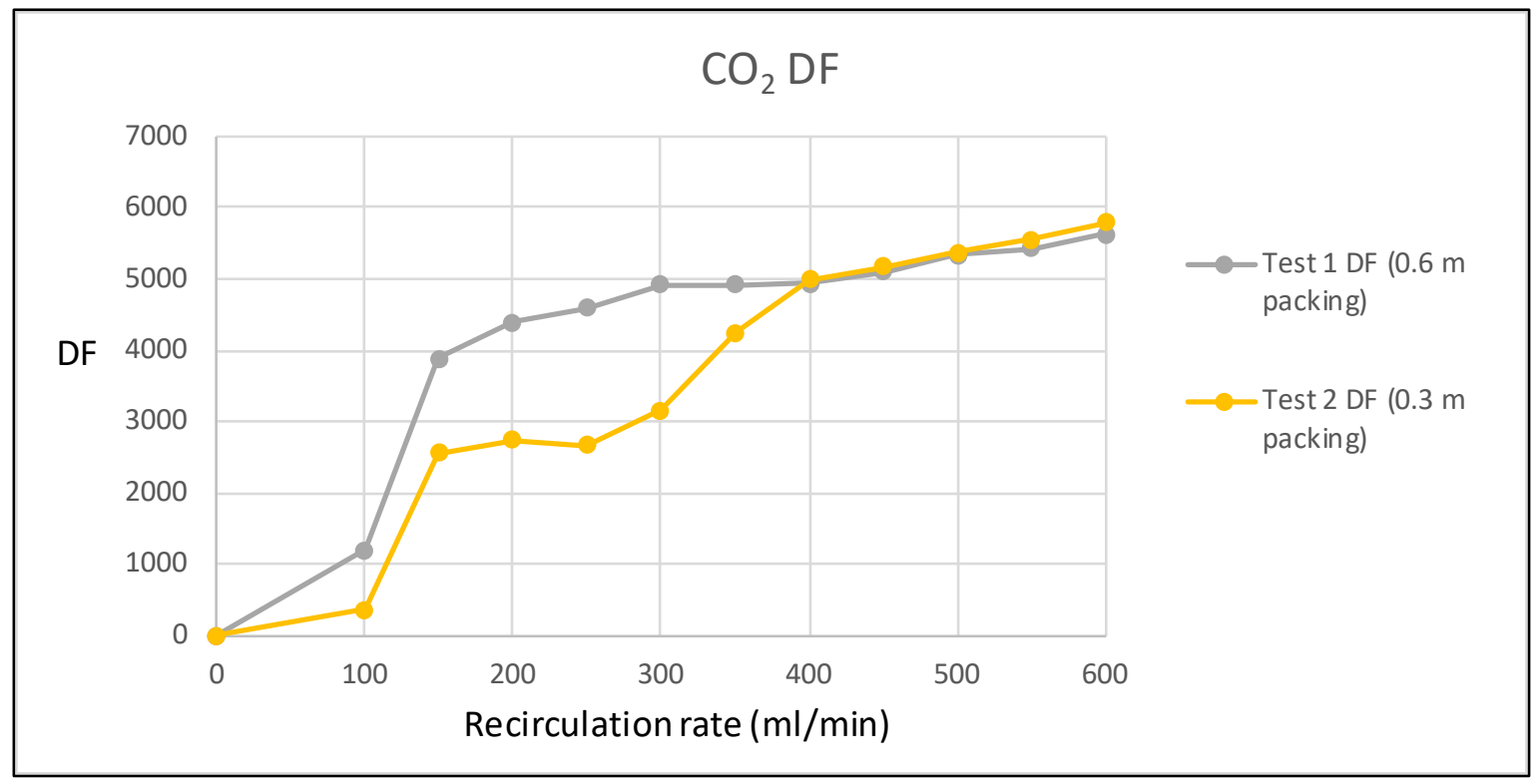

Figure 5. $\mathrm{CO}_{2} \mathrm{DF}$ as a function of packing length and scrub liquid recirculation rate.

Based on these results, the $\mathrm{CO}_{2}$ test matrix was revised to use a lower caustic recirculation rate, $0.1 \mathrm{l} / \mathrm{min}$, with the understanding that with the lower $\mathrm{L} / \mathrm{G}$ ratios, wetting conditions within the column would be poorer and thus the effluent $\mathrm{CO}_{2}$ concentration would be higher. It was intended that by increasing the effluent $\mathrm{CO}_{2}$ values, the observed differences between tests would be better resolved than those observed in Tables 3 and 4. Additionally, the LI-COR ${ }^{\circledR} \mathrm{CO}_{2}$ analyzer was zeroed prior to each test to remove the effects of instrument drift. In this series of tests, several test parameters were altered relative to the initial test matrix: the $\mathrm{CO}_{2}$ concentration was an independent variable (fixed in the initial series); the liquid rate was fixed at $100 \mathrm{ml} / \mathrm{min}$ and was removed as a variable in the test matrix along with the L/G. The gas rate was added as an additional independent variable in the tests matrix, (this case can then be thought of as the inverse of the $\mathrm{L} / \mathrm{G}$ independent variable).

The results of the second $\mathrm{CO}_{2}$ test matrix, performed at a low liquid recirculation rate, are shown in Table 6. With the exception of run 2-3, all tests still showed DFs $>100$. It is also important to note that in all runs except for run 2-3, the effluent concentration quickly reached a stable value and remained there for the duration of the test period. However, run 2-3 initially decreased to a low effluent value of $\sim 5{\mathrm{ppm} \mathrm{CO}_{2}}$ and then sharply rose to a value of $\sim 500 \mathrm{ppm} \mathrm{CO}_{2}$. It was observed to steadily increase to a final value of $725 \mathrm{ppm} \mathrm{CO} 2$ over the next $1.5 \mathrm{~h}$ as shown in Figure 6. The value of $557 \mathrm{ppm} \mathrm{CO}_{2}$ reflects the brief stable value observed at $\sim 0.2$ to 0.25 hours into the run. A replicate test showed similar results with respect to not reaching a stable $\mathrm{CO}_{2}$ effluent value. Figure 7 show a response curve typical of the other 7 runs.

As found in the initial test matrix, the longer packing length had a significant positive effect on the DF. Increasing the gas rate appeared to have a slightly negative impact on the DF. Neither the temperature nor the caustic concentration appeared to have any significant impact. It should be noted that to heat the system, the recirculating liquid was heated just prior to introducing it into the top of the column. While this was effective in the initial tests with significantly high recirculation rates, it was ineffective at the lower recirculation rates, which could not compensate for the heat losses from the column. Attempts made to preheat the column were also largely ineffective. Thus, while the goal was to operate at $40^{\circ} \mathrm{C}$, the actual temperature is believed to have been closer to ambient temperature, and thus it is unsurprising that no temperature effects were observed. As in the first test matrix, examination of the two "dummy factors" indicate that some process parameter interaction was likely occurring. 
Table 6. Phase 2 tests of scrubber to establish $\mathrm{CO}_{2}$ absorption efficiency (DF) and baseline parameters using low scrubber recirculation rates.

\begin{tabular}{|c|c|c|c|c|c|c|c|c|}
\hline \multirow{2}{*}{$\begin{array}{l}\text { Run } \\
\text { No. }\end{array}$} & \multirow{2}{*}{$\begin{array}{c}\mathrm{DF} \\
\text { response }\end{array}$} & Temp. & Gas rate & $\begin{array}{l}\text { Packing } \\
\text { length }\end{array}$ & $\mathrm{CO}_{2}$ conc. & $\begin{array}{l}\text { Caustic } \\
\text { conc. }\end{array}$ & \multirow{2}{*}{$\begin{array}{l}\text { Dummy } \\
\text { Factor } 1\end{array}$} & \multirow{2}{*}{$\begin{array}{l}\text { Dummy } \\
\text { Factor } 2\end{array}$} \\
\hline & & $\begin{array}{l}+=40^{\circ} \mathrm{C} \\
-=25^{\circ} \mathrm{C}\end{array}$ & $\begin{array}{l}+=1.25 \mathrm{l} / \mathrm{min} \\
-=0.75 \mathrm{l} / \mathrm{min}\end{array}$ & $\begin{array}{l}+=0.6 \mathrm{~m} \\
-=0.3 \mathrm{~m}\end{array}$ & $\begin{array}{c}+=15000 \mathrm{ppm} \\
-=400 \mathrm{ppm}\end{array}$ & $\begin{array}{l}+=1.0 \mathrm{M} \\
-=0.5 \mathrm{M}\end{array}$ & & \\
\hline $2-1$ & 117 & - & - & - & - & + & + & + \\
\hline $2-2$ & 4063 & + & - & - & + & + & - & - \\
\hline $2-3$ & 27 & - & + & - & + & - & + & - \\
\hline $2-4$ & 224 & + & + & - & - & - & - & + \\
\hline $2-5$ & 12448 & - & - & + & + & - & - & + \\
\hline $2-6$ & 166 & + & - & + & - & - & + & - \\
\hline $2-7$ & 229 & - & + & + & - & + & - & - \\
\hline $2-8$ & 11420 & + & + & + & + &.+ & + & + \\
\hline$\Sigma+$ & 28694 & 15873 & 11900 & 24263 & 27959 & 15829 & 11730 & 24208 \\
\hline$\Sigma-$ & & 12821 & 16794 & 4431 & 736 & 12865 & 16965 & 4486 \\
\hline$\Delta$ & & 3052 & -4894 & 19832 & 27223 & 2964 & -5235 & 19722 \\
\hline Effect & & 763 & -1223 & 4958 & 6806 & 741 & -1309 & 4931 \\
\hline
\end{tabular}

Note: Dummy Factors column may be used to estimate the experimental error or presence of interactions between the process variables associated with the results of the individual runs.

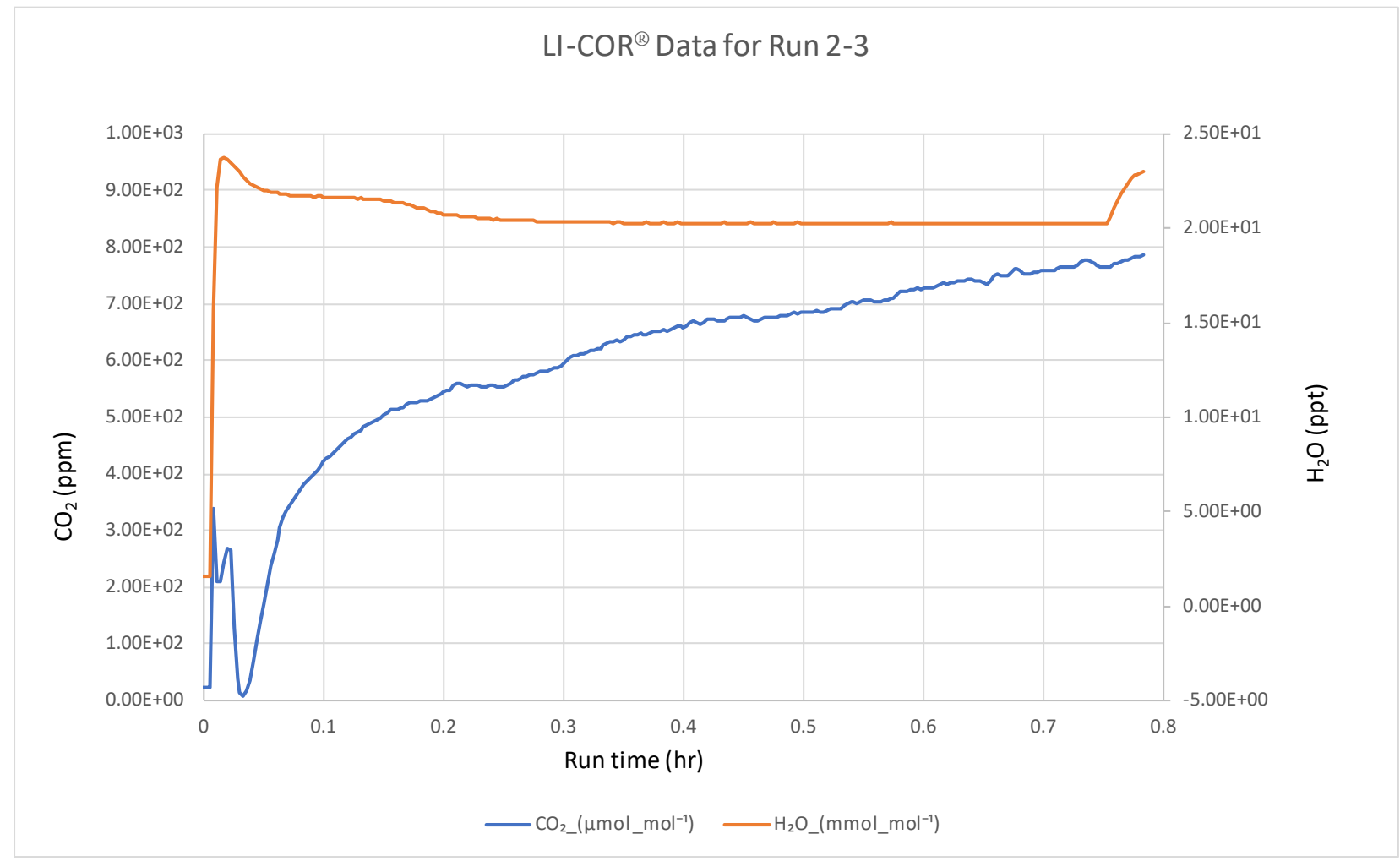

Figure 6. $\mathrm{CO}_{2}$ and water in run 2-3 effluent. 


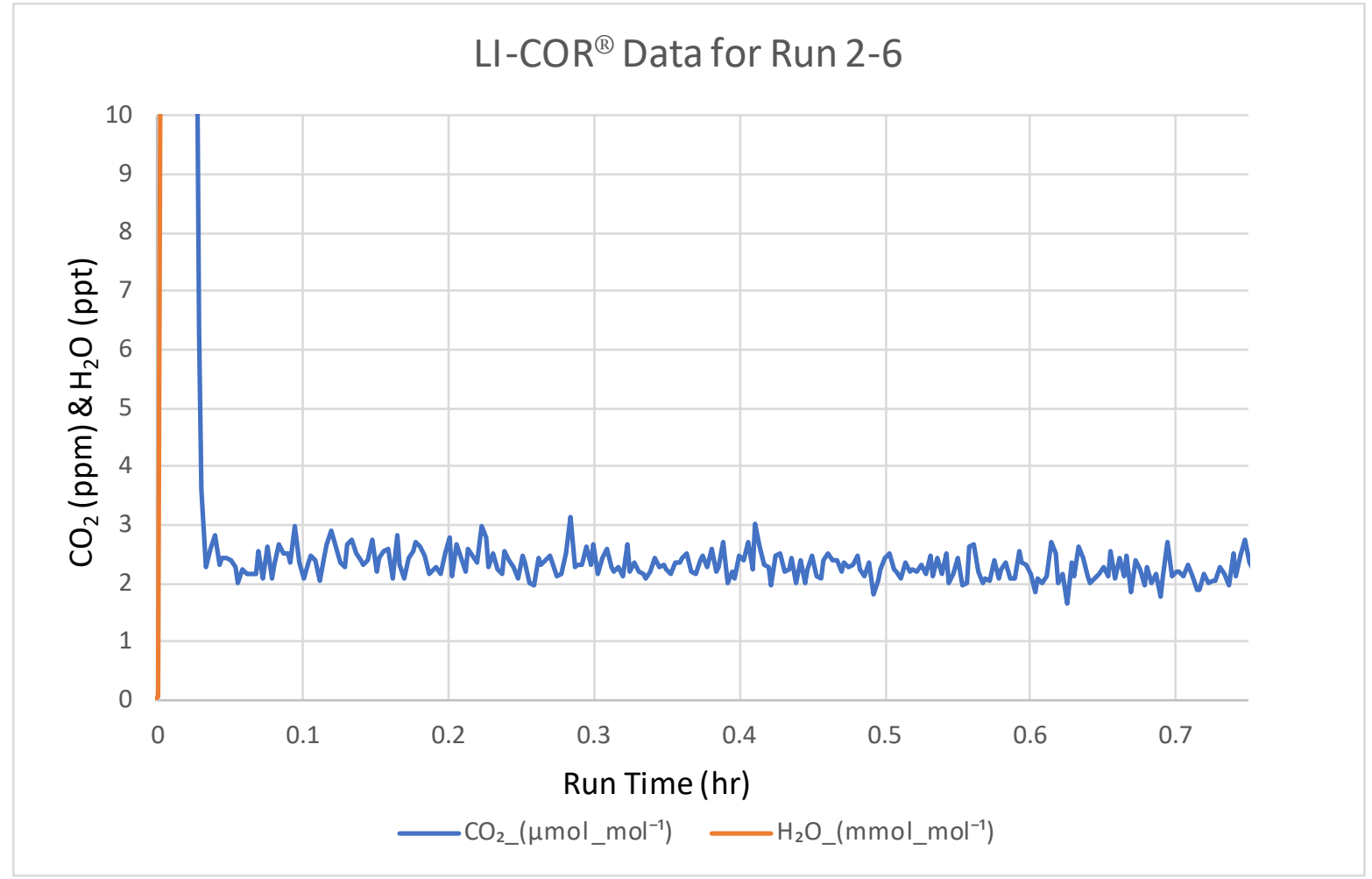

Figure 7. $\mathrm{CO}_{2}$ and water in run 2-6 effluent.

The effect of using higher $\mathrm{CO}_{2}$ inlet concentrations appears to have a very significant positive effect on the $\mathrm{CO}_{2} \mathrm{DF}$ for the scrubber. However, since the DF is calculated from the inlet $\mathrm{CO}_{2}$ concentration as per Equation 1, this conclusion is not unexpected.

$$
\begin{gathered}
\text { Equation } 1 \\
\text { Decontamination Factor }=\frac{\left[\mathrm{CO}_{2}\right] \text { inlet }}{\left[\mathrm{CO}_{2}\right] \text { effluent }}
\end{gathered}
$$

To remove the coupled effect of DF and $\mathrm{CO}_{2}$ inlet concentration, Table 7 examines this data in term of the effects of the process variables on the effluent concentration, which is the actual measured, dependent variable.

Evaluating the data in this way resulted in no real information, because the statistical analysis was dominated by the high $\mathrm{CO}_{2}$ effluents observed in run 2-3. It was noted that all conditions used in run 2-3 would be expected to be the most adverse for $\mathrm{CO}_{2}$ capture. As noted above, the effluent concentration in run 2-3 was initially low but began to rise within 5 min of test initiation and never reaching a steady-state value. To further understand the effect of this particular run on the conclusions drawn using the statistical test matrix, a sensitivity analysis was performed, and its specifics are shown in Tables 8 and 9 . Table 8 considers the effects of the range of observed Run 2-3 DFs (1518 to 22) on the conclusions of the statistical test matrix, and Table 9 shows the effects of observed Run 2-3 effluent $\mathrm{CO}_{2}$ concentrations (10 to 700) associated with the DFs in Table 8. The results shown in both Tables 8 and 9 are completely consistent with the results shown in Table 6. Seven of the eight runs resulted in steady-state effluent concentrations that range from $1.22 \mathrm{ppm}$ to $3.74 \mathrm{ppm}$. For each independent variable, four runs were conducted at the high value and four at the low value. The net effect of the variable is the sum of the resulting dependent variables for the four positive or high-value runs minus the sum of the resulting dependent variables for the four low-value runs divided by 4 to estimate the effect of the independent 
variable. From the data of the eight runs, it is very clear that run 2-3 gave the poorest performance of any in terms of scrubbing performance (i.e., has the highest $\mathrm{CO}_{2}$ effluent concentration). If a single independent variable results in a dependent variable value that is an order of magnitude or greater different from all the other values, it mathematically dominates the calculations and the net effects for all independent variables tend toward a value of the single dominant value divided by 4 (as is observed in Table 7). But also note that at no point does the direction of the net effect change (i.e., positive or negative) nor does the relative order of the net effects within a row change. In all cases, the length of the column had the greatest effect on the effluent; shorter columns resulted in higher effluent concentration (which would decrease the associated DF). Increasing the $\mathrm{CO}_{2}$ inlet concentration had a small positive effect on the effluent concentration, and increasing the scrubber temperature appeared to have a slightly negative effect on effluent concentration. The gas rate and caustic concentration had little or no effect.

Table 7. Phase 2 tests of scrubber to establish $\mathrm{CO}_{2}$ absorption efficiency (effluent concentration) and baseline parameters using low scrubber recirculation rates.

\begin{tabular}{|c|c|c|c|c|c|c|c|c|}
\hline \multirow{2}{*}{$\begin{array}{c}\text { Run } \\
\text { No. }\end{array}$} & $\begin{array}{c}\mathrm{CO}_{2} \text { in } \\
\text { effluent } \\
\text { response }\end{array}$ & Temp. & Gas rate & $\begin{array}{c}\text { Packing } \\
\text { length }\end{array}$ & $\mathrm{CO}_{2}$ conc. & $\begin{array}{c}\text { Caustic } \\
\text { conc. }\end{array}$ & $\begin{array}{c}\text { Dummy } \\
\text { Factor 1 }\end{array}$ & $\begin{array}{c}\text { Dummy } \\
\text { Factor } 2\end{array}$ \\
\hline $2-1$ & 3.48 & - & - & - & - & + & + & + \\
\hline $2-2$ & 3.74 & + & - & - & + & + & - & - \\
\hline $2-3$ & 557 & - & + & - & + & - & + & - \\
\hline $2-4$ & 1.76 & + & + & - & - & - & - & + \\
\hline $2-5$ & 1.22 & - & - & + & + & - & - & + \\
\hline $2-6$ & 2.32 & + & - & + & - & - & + & - \\
\hline $2-7$ & 1.79 & - & + & + & - & + & - & - \\
\hline $2-8$ & 1.33 & + & + & + & + &.+ & + & + \\
\hline$\Sigma+$ & 573 & 9 & 562 & 7 & 563 & 10 & 564 & 8 \\
\hline$\Sigma-$ & & 563 & 11 & 566 & 9 & 562 & 9 & 565 \\
\hline$\Delta$ & & -554 & 551 & -559 & 554 & -552 & 556 & -557 \\
\hline Effect & & -139 & 138 & -140 & 138 & -138 & 139 & -139 \\
\hline
\end{tabular}

Note: Dummy Factors column may be used to estimate the experimental error or presence of interactions between the process variables associated with the results of the individual runs. 
Table 8. Examination of the impact of variation in run 2-3 DF on effects analysis of independent variables.

\begin{tabular}{|c|c|c|c|c|c|c|c|c|}
\hline \multirow{3}{*}{$\begin{array}{l}\text { Run 2-3 } \\
\text { effluent } \\
\text { conc. } \\
\text { (ppm) }\end{array}$} & \multirow{3}{*}{$\begin{array}{c}\mathrm{DF} \\
\text { response }\end{array}$} & \multicolumn{7}{|c|}{ Net effects } \\
\hline & & Temp. & Gas rate & $\begin{array}{c}\text { Packing } \\
\text { length }\end{array}$ & $\mathrm{CO}_{2}$ conc. & $\begin{array}{c}\text { Caustic } \\
\text { conc. }\end{array}$ & \multirow[b]{2}{*}{$\begin{array}{l}\text { Dummy } \\
\text { Factor } 1\end{array}$} & \multirow[b]{2}{*}{$\begin{array}{l}\text { Dummy } \\
\text { Factor } 2\end{array}$} \\
\hline & & $\begin{array}{l}+=40^{\circ} \mathrm{C} \\
-=25^{\circ} \mathrm{C}\end{array}$ & $\begin{array}{l}+=1.25 \mathrm{l} / \mathrm{min} \\
-=0.75 \mathrm{l} / \mathrm{min}\end{array}$ & $\begin{aligned}+ & =0.6 \mathrm{~m} \\
- & =0.3 \mathrm{~m}\end{aligned}$ & $\begin{array}{c}+=15000 \\
\text { ppm } \\
-=400 \mathrm{ppm}\end{array}$ & $\begin{array}{l}+=1.0 \mathrm{M} \\
-=0.5 \mathrm{M}\end{array}$ & & \\
\hline 10 & 1518 & 390 & -851 & 4585 & 7178 & 368 & -936 & 4558 \\
\hline 50 & 304 & 694 & -1154 & 4889 & 6875 & 672 & -1240 & 4861 \\
\hline 100 & 224 & 732 & -1192 & 4927 & 6837 & 710 & $\begin{array}{l}-1278 \\
\end{array}$ & 4899 \\
\hline 400 & 38 & 760 & -1221 & 4955 & 6808 & 738 & -1306 & 4928 \\
\hline 500 & 30 & 762 & -1223 & 4957 & 6807 & 740 & -1308 & 4930 \\
\hline 557 & 27 & 763 & $\begin{array}{l}-1223 \\
\end{array}$ & 4958 & 6806 & 741 & -1309 & 4931 \\
\hline 600 & 25 & 764 & -1224 & 4958 & 6805 & 741 & -1309 & 4931 \\
\hline 700 & 22 & 764 & -1225 & 4959 & 6804 & 742 & -1310 & 4932 \\
\hline
\end{tabular}

Note: Dummy Factors column may be used to estimate the experimental error or presence of interactions between the process variables associated with the results of the individual runs.

Table 9. Examination of the impact of variation in run 2-3 effluent concentration on effects analysis of independent variables.

\begin{tabular}{|c|c|c|c|c|c|c|c|}
\hline \multirow{3}{*}{$\begin{array}{c}\mathrm{CO}_{2} \text { in } \\
\text { Run 2-3 } \\
\text { effluent } \\
\text { (ppm) }\end{array}$} & \multicolumn{7}{|c|}{ Net effects } \\
\hline & Temp. & Gas rate & $\begin{array}{c}\text { Packing } \\
\text { length }\end{array}$ & $\mathrm{CO}_{2}$ conc. & $\begin{array}{c}\text { Caustic } \\
\text { conc. }\end{array}$ & $\begin{array}{l}\text { Dummy } \\
\text { Factor } 1 \\
\end{array}$ & $\begin{array}{l}\text { Dummy } \\
\text { Factor } 2 \\
\end{array}$ \\
\hline & $\begin{array}{l}+=40^{\circ} \mathrm{C} \\
-=25^{\circ} \mathrm{C}\end{array}$ & $\begin{array}{l}+=1.25 \mathrm{l} / \mathrm{min} \\
-=0.75 \mathrm{l} / \mathrm{min}\end{array}$ & $\begin{array}{l}+=0.6 \mathrm{~m} \\
-=0.3 \mathrm{~m}\end{array}$ & $\begin{array}{l}+=15,000 \mathrm{ppm} \\
-=400 \mathrm{ppm}\end{array}$ & $\begin{array}{l}+=1.0 \mathrm{M} \\
-=0.5 \mathrm{M}\end{array}$ & & \\
\hline 10 & -1.8 & 1.0 & -3.1 & 1.7 & -1.2 & 2.2 & -2.5 \\
\hline 50 & -11.8 & 11.0 & -13.1 & 11.7 & -11.2 & 12.2 & -12.5 \\
\hline 100 & -24.3 & 23.5 & -25.6 & 24.2 & -23.7 & 24.7 & -25.0 \\
\hline 400 & -99.3 & 98.5 & -100.6 & 99.2 & -98.7 & 99.7 & -100.0 \\
\hline 500 & -124.3 & 123.5 & -125.6 & 124.2 & -123.7 & 124.7 & -125.0 \\
\hline 557 & -138.6 & 137.8 & -139.8 & 138.5 & -138.0 & 138.9 & -139.3 \\
\hline 600 & -149.3 & 148.5 & -150.6 & 149.2 & -148.7 & 149.7 & -150.0 \\
\hline 700 & -174.3 & 173.5 & -175.6 & 174.2 & -173.7 & 174.7 & -175.0 \\
\hline
\end{tabular}

Note: Dummy Factors column may be used to estimate the experimental error or presence of interactions between the process variables associated with the results of the individual runs.

\subsection{Scrubber lodine Capture Results}

The original intent of the structured iodine performance matrix was to examine the impacts of varying only iodine concentration and packing length while the temperature, liquid rate, and $\mathrm{L} / \mathrm{G}$ are at values that showed positive impacts on $\mathrm{CO}_{2}$ scrubbing performance. However, the challenge faced in the $\mathrm{CO}_{2}$ test matrix was to find conditions that were inefficient enough to produce measurable $\mathrm{CO}_{2}$ in the effluent. As a result, it was decided to conduct a single iodine scrubber test at a condition that should produce relatively poor performance to set a lower bounding condition and to conduct the integrated scrubber-polishing bed test at conditions that should result in highly efficient scrubbing. The conditions for the low efficiency iodine scrubbing tests were to utilize the same flowrates, process parameters and column configuration as used in run 2-1. 
The conditions selected for the lower bounding iodine scrubbing tests were:

$\begin{array}{ll}\text { Packing length } & 0.3 \mathrm{~m} \\ \text { Liquid rate } & 100 \mathrm{ml} / \mathrm{min} \\ \text { Gas rate } & 0.75 \mathrm{l} / \mathrm{min} \\ \text { Temperature } & 23^{\circ} \mathrm{C} \text { (ambient) } \\ \text { NaOH } & 1.0 \mathrm{~N} \\ \text { Iodine conc. } & 100 \mathrm{ppm} \text { or higher }\end{array}$

This test ran for 8 hours. At the end of the test, both the scrubber bottoms tank and the effluent bubbler were analyzed. The results indicated that only $0.74 \%$ of the iodine passed through the scrubber for a DF of 134. This value can be compared to the $\mathrm{CO}_{2}$ DF of 117 reported for run 2-1 in Table 6 .

\subsection{Combined lodine Scrubber and Polishing Bed}

\subsubsection{Extended Scrubber Performance}

All liquid samples removed from the scrubber bottoms during testing, as well as the accumulated condenser liquid and final scrubber solution, were analyzed by ICP-MS to determine iodine content. The volume of scrubber solution at any given time was corrected to account for the ongoing evaporation (309 $\mathrm{ml}$ over the course of testing), some seepage around several fittings (determined to be $\sim 220 \mathrm{ml}$ over the course of the test), and removal $(521 \mathrm{ml})$ and addition $(500 \mathrm{ml})$ of liquid during test operation for sampling and makeup operations. The iodine feed rate was $1107 \pm 109 \mu \mathrm{g} / \mathrm{min}$ based on two separate feed gas bubbler samples. Those corrections are reflected in Table 10. Figure 8 shows the calculated iodine concentration in the scrubber bottoms tank based on measurements of iodine concentration in the feed stream and the corrected liquid inventory. Note that at 6.23 days into the run, $500 \mathrm{ml}$ of fresh $1.0 \mathrm{~N} \mathrm{NaOH}$ was added. This addition corresponds to the decrease in $\mathrm{I}_{2}$ concentration observed for the samples taken on day 7 of the run.

Table 10. Comparison of cumulative iodine fed to scrubber and iodine accumulation in scrubber bottoms tank.

\begin{tabular}{|c|c|c|c|}
\hline $\begin{array}{c}\text { Test time } \\
(\text { days })\end{array}$ & $\begin{array}{c}\mathrm{I}_{2} \text { delivered } \\
(\mathrm{g})\end{array}$ & $\begin{array}{c}\text { Calculated }\left[\mathrm{I}_{2}\right] \text { in } \\
\text { solution (assuming } 100 \% \\
\text { capture })(\mu \mathrm{g} / \mathrm{mL})\end{array}$ & $\begin{array}{c}\text { Iodine content in } \\
\text { scrubber bottoms } \\
(\text { analytical results) } \\
\left(\mu \mathrm{g} \mathrm{I}_{2} / \mathrm{mL}\right)\end{array}$ \\
\hline 0.22 & 0.09 & 64 & 36 \\
\hline 1.03 & 0.45 & 322 & 285 \\
\hline 1.81 & 0.79 & 587 & 547 \\
\hline 3.25 & 1.42 & 1135 & 957 \\
\hline 4.41 & 1.92 & 1631 & 1450 \\
\hline 5.18 & 2.26 & 1997 & 2310 \\
\hline 6.23 & 2.72 & 2549 & 1450 \\
\hline 7.22 & 3.14 & 1989 & 2300 \\
\hline 8.17 & 3.56 & 2358 & 3180 \\
\hline 9.15 & 3.98 & 2777 & 3180 \\
\hline 10.15 & 4.42 & 3254 & 3100 \\
\hline 10.15 & 4.42 & 3254 & 3200 \\
\hline 10.15 & 4.42 & 3254 & \\
\hline 10.15 & 4.42 & 3254 & \\
\hline
\end{tabular}


The overall iodine material balance was determined to be $93.62 \%$ based on the analytical results, removal of analytical samples, and seepage losses. Analytical measurements have an associated uncertainty of 10\%, thus the iodine material balance was closed within levels that could be measured via ICP-MS.

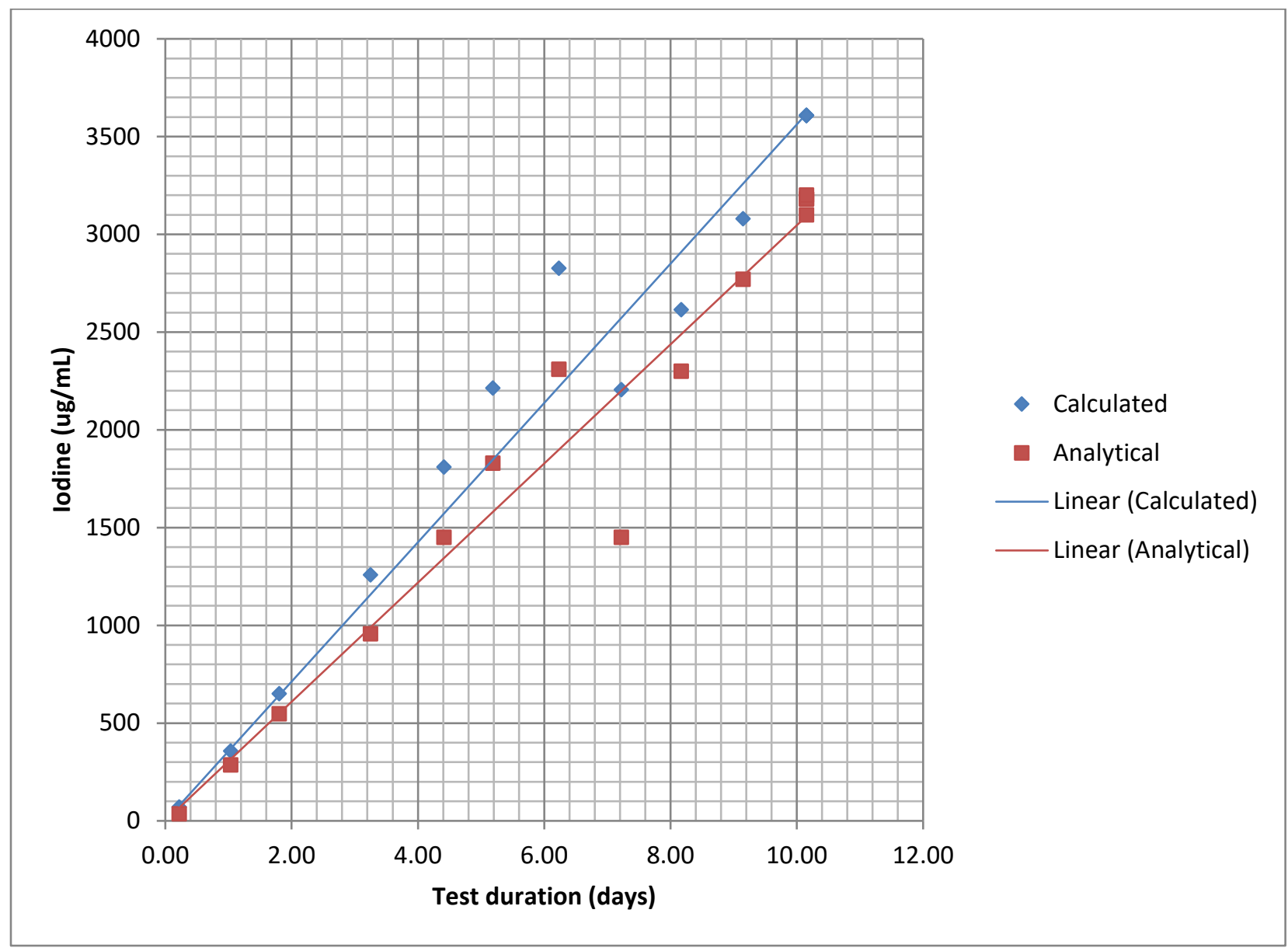

Figure 8. Calculated and analytically measured iodine concentration in the scrubber bottoms tank for the integrated iodine scrubber and polishing bed test.

\subsection{2 lodine Loading on the Polishing Bed}

Previous work has shown up to 27\% variability in the iodine content of I-AgZ removed from a deep bed (Jubin et al. 2017b). For each segment analyzed in this testing, up to four subsamples were analyzed to allow quantification of this variability. This experimentally determined variability is reported with each value included in Table 11. It was found that the first segment of the bed (Segment A) had an average iodine loading of $0.1103 \mathrm{mg} \mathrm{I} / \mathrm{g} \mathrm{AgZ}$. The standard deviation of the four sample results was $0.0298 \mathrm{mg} \mathrm{I} / \mathrm{g}$ AgZ or 27\%, consistent with previous observations. The remainder of the analyzed segments were below detection limit, which is designated as "MDA" in Table 11. As shown in the table, detectable levels of iodine were seen only in the first $0.7 \mathrm{~cm}$ of the polishing bed. The total amount of iodine collected in the polishing bed was $0.0079 \%$. This would imply an iodine DF for the scrubber of over 12,700 , assuming that the sorbent bed quantitatively removed all iodine that passed through the scrubber. 
Table 11. Iodine loading on iodine polishing bed segments.

\begin{tabular}{|l|l|l|l|l|l|}
\hline $\begin{array}{c}\text { Segment } \\
\text { designation }\end{array}$ & $\begin{array}{c}\text { Segment } \\
\text { msss } \\
(\mathrm{g})\end{array}$ & $\begin{array}{c}\text { Segment } \\
\text { length } \\
(\mathrm{cm})\end{array}$ & $\begin{array}{c}\text { Cumulative } \\
\text { length } \\
(\mathrm{cm})\end{array}$ & $\begin{array}{c}\text { Average iodine } \\
\text { loading } \\
(\mathrm{mg} \mathrm{I} / \mathrm{g} \text { AgZ })\end{array}$ & $\begin{array}{c}\text { Total iodine in } \\
\text { segment } \\
(\mathrm{mg})\end{array}$ \\
\hline IT1-A (inlet) & 3.4971 & 0.65 & 0.65 & $0.1103 \pm 0.0344$ & $0.3856 \pm 0.0132$ \\
\hline IT1-B & 4.7489 & 0.89 & 1.54 & MDA* & MDA \\
\hline IT1-C & 5.5261 & 1.03 & 2.57 & MDA & MDA \\
\hline IT1-D & 5.9044 & 1.10 & 3.67 & Not analyzed & Not analyzed \\
\hline IT1-E & 6.1044 & 1.14 & 4.81 & MDA & MDA \\
\hline IT1-F & 4.8503 & 0.91 & 5.72 & Not analyzed & Not analyzed \\
\hline IT1-G & 7.3098 & 1.36 & 7.08 & MDA & MDA \\
\hline IT1-H & 10.7300 & 2.00 & 9.08 & Not analyzed & Not analyzed \\
\hline IT1-I & 11.8654 & 2.21 & 11.30 & MDA & MDA \\
\hline IT1-J (outlets) & 12.6235 & 2.36 & 13.65 & Not analyzed & Not analyzed \\
\hline
\end{tabular}

*MDA = below minimum detectable activity.

\section{4 lodine Loading on Solid Sorbent Bed without Scrubber}

To determine the impact of the scrubber, a similar test was conducted without the scrubber in place. An iodine stream was generated and passed through a sorbent bed with $71.2799 \mathrm{~g}$ of AgZ. The gas flow rate was still $1.001 \mathrm{l} / \mathrm{min}$, with an $\mathrm{I}_{2}$ concentration of $335.6 \mu \mathrm{g} / \mathrm{min}(33 \mathrm{ppmv})$. The effluent of the bed was periodically sampled by passing it through a $1 \mathrm{M} \mathrm{NaOH}$ bubbler. The concentration of iodine leaving the AgZ bed was anticipated to likely be much lower than that entering the bed, as the bubblers were run for long periods of time, typically $\sim 8 \mathrm{hr}$ or overnight. The results of this test are shown in Table 12 . The reported uncertainty in the iodine concentration was $\pm 10 \%$. It is believed that there may have been some contamination of the first bubbler during testing. With the exception of the first bubbler, no iodine was recovered in the bubblers until sometime on August 16, 2018 (or until after about 180 hours into the 256hour run). At this point the observed DF of $>3000$ for all sampling periods except the first dropped to $\sim 40$ and continued to decline to near 1.5 at the end. Of the 5.16 gm of iodine fed to the system (based on the average of two iodine feed gas samples), $0.655 \mathrm{~g}$ was collected in the bubblers.

Table 12. Data obtained from iodine effluent sampler following iodine polishing bed without leading caustic scrubber

\begin{tabular}{|c|c|c|c|c|c|c|c|c|}
\hline \multirow{2}{*}{$\begin{array}{c}\text { Bubbler } \\
\text { ID }\end{array}$} & \multicolumn{2}{|c|}{ On line } & \multicolumn{2}{|c|}{ Off line } & \multirow{2}{*}{$\begin{array}{l}\text { Iodine } \\
\mu \mathrm{g} / \mathrm{ml}\end{array}$} & \multicolumn{2}{|c|}{ Total iodine captured } & \multirow[t]{2}{*}{ Period DF } \\
\hline & Date & Time & Date & Time & & $\mu g$ & $\mu \mathrm{g} / \mathrm{min}$ & \\
\hline IT2 - aq3 & 8/10/2018 & $8: 57$ & 8/10/2018 & & 2.13 & 515.5 & 1.26 & 270 \\
\hline IT2 - aq4 & $8 / 13 / 2018$ & $9: 31$ & $8 / 13 / 2018$ & $15: 36$ & 0.17 & 40.2 & 0.11 & 3052 \\
\hline IT2 - aq5 & $8 / 14 / 2018$ & $7: 28$ & 8/14/2018 & $15: 28$ & 0.10 & 23.4 & 0.05 & 6884 \\
\hline IT2 - aq6 & $8 / 15 / 2018$ & $7: 29$ & $8 / 16 / 2018$ & $9: 24$ & 0.09 & 20.8 & 0.01 & 25072 \\
\hline IT2 - aq7 & $8 / 16 / 2018$ & $9: 47$ & $8 / 17 / 2018$ & $7: 05$ & 47.00 & 10105.0 & 7.91 & 42 \\
\hline IT2 - aq8 & $8 / 17 / 2018$ & $7: 15$ & $8 / 17 / 2018$ & $16: 54$ & 92.20 & 21943.6 & 37.90 & 8.9 \\
\hline IT2 - aq9 & $8 / 18 / 2018$ & $6: 46$ & $8 / 18 / 2018$ & $17: 44$ & 473.00 & 111628.0 & 169.65 & 2.0 \\
\hline IT2 - aq10 & $8 / 18 / 2018$ & $17: 52$ & $8 / 20 / 2018$ & $6: 58$ & 2430.00 & 510300.0 & 229.25 & 1.5 \\
\hline
\end{tabular}

The AgZ bed was sampled by vacuum removal into discrete segments. From each segment, three subsamples were taken for analysis. This experimentally determined variability is reported with each value included in Table 13. Based on the triplicate sample analysis, the average standard deviation of each of the sets was 4.6\%. Each of the first eight segments (IT2-A through IT2-H) had loadings in excess of $82 \mathrm{mg} \mathrm{I/g}$ AgZ with an average loading of $88.77 \mathrm{mg} \mathrm{I} / \mathrm{g}$ AgZ. Beginning with segment IT2-I a gradual decrease in 
loading occurred, consistent with the start of the mass transfer zone. The iodine loading profile is shown in Figure 9. The total amount of iodine collected in the sorbent bed was $6.163 \pm 0.277 \mathrm{~g}$ of $\mathrm{I}_{2}$. The overall iodine material balance was $132.0 \%$ based on the average of two iodine feed gas samples.

Table 13. Iodine loading on iodine polishing bed segments without leading caustic scrubber.

\begin{tabular}{|l|l|l|l|l|l|}
\hline $\begin{array}{c}\text { Segment } \\
\text { designation }\end{array}$ & $\begin{array}{c}\text { Segment } \\
\text { mass } \\
(\mathrm{g})\end{array}$ & $\begin{array}{c}\text { Segment } \\
\text { length } \\
(\mathrm{cm})\end{array}$ & $\begin{array}{c}\text { Cumulative } \\
\text { length } \\
(\mathrm{cm})\end{array}$ & $\begin{array}{c}\text { Average iodine } \\
\text { loading } \\
(\mathrm{mg} \mathrm{I/g} \mathrm{AgZ)}\end{array}$ & $\begin{array}{c}\text { Total iodine in } \\
\text { segment } \\
(\mathrm{mg})\end{array}$ \\
\hline IT2-A (inlet) & 4.3646 & 0.73 & 0.73 & $93.028 \pm 3.724$ & $0.371 \pm 0.015$ \\
\hline IT2-B & 4.1453 & 0.70 & 1.43 & $89.906 \pm 5.468$ & $0.373 \pm 0.021$ \\
\hline IT2-C & 6.3532 & 1.07 & 2.49 & $89.906 \pm 4.967$ & $0.571 \pm 0.029$ \\
\hline IT2-D & 6.8495 & 1.15 & 3.64 & $92.777 \pm 3.2705$ & $0.635 \pm 0.020$ \\
\hline IT2-E & 4.9462 & 0.83 & 4.47 & $90.120 \pm 6.361$ & $0.446 \pm 0.029$ \\
\hline IT2-F & 5.822 & 0.98 & 5.45 & $86.413 \pm 2.571$ & $0.503 \pm 0.014$ \\
\hline IT2-G & 5.5515 & 0.93 & 6.38 & $83.541 \pm 4.072$ & $0.464 \pm 0.021$ \\
\hline IT2-H & 11.5151 & 1.93 & 8.31 & $84.434 \pm 3.396$ & $0.972 \pm 0.036$ \\
\hline IT2-I & 12.7714 & 2.14 & 10.45 & $77.679 \pm 3.043$ & $0.992 \pm 0.036$ \\
\hline IT2-J (outlet) & 17.1843 & 2.88 & 13.34 & $76.902 \pm 3.537$ & $1.231 \pm 0.056$ \\
\hline
\end{tabular}

*MDA = below minimum detectable activity.

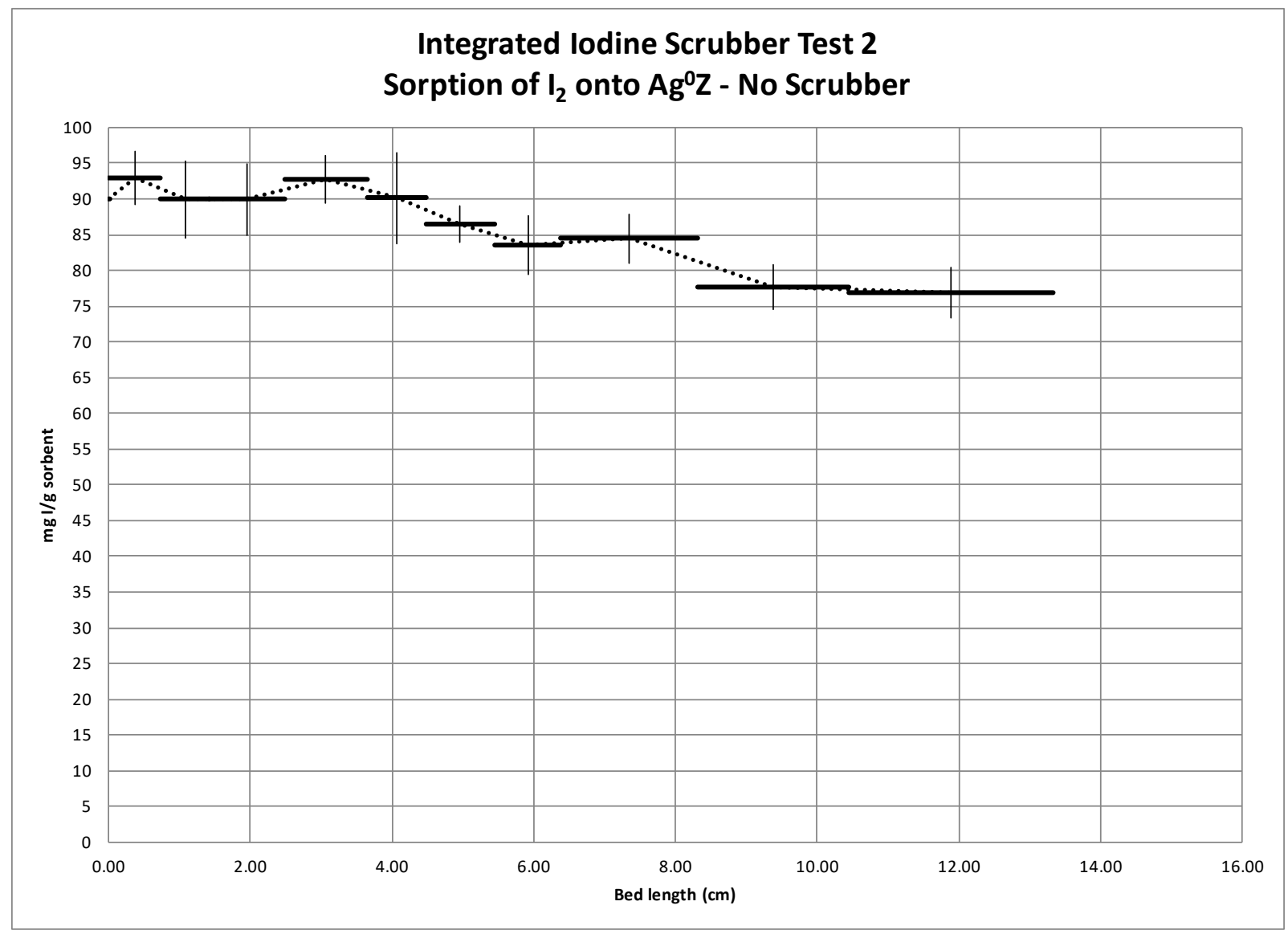

Figure 9. Iodine loading profile in the iodine polishing bed with the caustic scrubber off-line. 


\section{CONCLUSIONS AND RECOMMENDATIONS}

This report describes a relatively simple test bed in which the performance of an iodine scrubber system was evaluated using a structured set of tests that culminated in the demonstration of a combined scrubber system coupled with a silver-based solid sorbent bed for final iodine polishing.

Initial testing of the scrubber system was conducted to characterize $\mathrm{CO}_{2}$ removal by the aqueous $\mathrm{NaOH}$ scrubber as a function of temperature, caustic concentration, packing length, liquid-to-gas mass ratio, and liquid flow rate. It was found that when the column was well wetted, very high $\mathrm{CO}_{2}$ DFs were achieved (>650 and potentially as high as 15,000). This high removal efficiency hindered the ability to clearly elucidate the effects of each specific variable tested. The most significant effects appeared to arise from the packing length and the temperature. The $\mathrm{L} / \mathrm{G}$ ratio used to achieve good wetting was not representative of typical L/G ratios found in industrial-scale scrubber systems. By significantly lowering the liquid recirculation rate to the point that column wetting was marginal, some significant variations in the $\mathrm{CO}_{2} \mathrm{DF}$ or $\mathrm{CO}_{2}$ effluent concentrations could be observed. The most significant operational parameter under these adverse operating conditions appeared to be column length; longer was better, which is commensurate with engineering principles.

Following these $\mathrm{CO}_{2}$ tests, a single iodine scrubber test was performed at a condition, based on the $\mathrm{CO}_{2}$ tests, that would result in poor column performance but would also establish a lower performance bound. The result showed that even under these adverse operating conditions, an iodine DF of $>100$ could be achieved.

Finally, the aqueous scrubber and a AgZ polishing bed were integrated and tested. This simple caustic scrubber system achieved an iodine DF of $>12,000$. Using this iodine DF, the iodine loading on the polishing bed is reduced by $99.993 \%$.

The performance of the integrated system was compared to that of a system including an AgZ sorbent bed alone. The system without the scrubber also showed DFs greater than 3000 until breakthrough was observed. The loading on the saturated portion of the bed averaged $88.8 \mathrm{mg} \mathrm{I} / \mathrm{gm}$ AgZ. Comparing the penetration of iodine into the sorbent beds for these two systems shows a marked difference; the penetration with the scrubber on line was only $0.65 \mathrm{~cm}$ and the maximum loading was $0.11 \mathrm{mg} \mathrm{I} / \mathrm{gm}$ AgZ, whereas for the case without the caustic scrubber, the bed was loaded to saturation for the first 8-9 $\mathrm{cm}$ and iodine breakthrough of the $13.3 \mathrm{~cm}$ bed occurred.

These observations provide an indication of the potential for an integrated test system consisting of an aqueous scrubber and a AgZ polishing bed to achieve reasonable system DFs while extending the life of the solid sorbent bed from weeks to months or years. These observed DFs are currently for elemental iodine only. Under such conditions, the sorbent usage could be decreased by a factor of 100 to 1000 even assuming that the sorbent loading would be reduced by a factor of 50 to $75 \%$. If it is assumed that up to $5 \%$ of the iodine in the DOG is organic iodides and that these pass through the scrubber unabated, the overall scrubber DF would be reduced to $\sim 20$. This $5 \%$ residual iodine is the primary iodine challenge for the sorbent, and assuming that the loading is comparable or degraded by $20 \%$, the amount of sorbent required is still reduced by $94 \%$. These changes directly affect bed replacement frequency.

Tests by Soelberg and Watson (2016) focused on the adsorption of $\mathrm{CH}_{3} \mathrm{I}$ on $\mathrm{AgZ}$ and silver-functionalized silica-aerogel indicate that the organic moiety is cleaved in the adsorption bed and that the iodine in the effluent at breakthrough and beyond can be captured in a caustic. Their tests showed that as the DF in the deep system decreased due to sorbent capacity depletion, the fraction of the iodine in the effluent observed as soluble in $\mathrm{NaOH}$ increased to the point that by the end of the test, $99.9 \%$ of the unabsorbed iodine was not $\mathrm{CH}_{3} \mathrm{I}$ but species retained in the $\mathrm{NaOH}$. Thus, it may be possible to couple a short AgZ bed prior to the scrubber not to capture iodine but to allow it to act as a catalyst bed to react the organic iodides and produce a soluble iodine form. The expected degradation of iodine capture capacity in this leading bed is not the relevant issue. In fact, based on the reported data, such a loss of capacity would be desirable. 
Future work should include completing the test matrices proposed in the scrubber test plan and also exploring the possibility of converting the organic iodides to soluble forms by use of a catalyst bed or iodine-loaded AgZ bed.

\section{REFERENCES}

Anderson, K. K., S. H. Bruffey, D. L. Lee, R. T. Jubin, and J. F. Walker. 2012. Iodine Loading of Partially Reduced Silver Mordenite. FCRD-SWF-2013-000079. US Department of Energy Separations and Waste Forms Campaign. December.

ChemGlass. 2018. 3L Gas Scrubbers, Complete. https://chemglass.com/3l-gas-scrubbers-complete.

Jubin, R. T. 2011. Report of the FY11 Activities of the Off-Gas Sigma Team. FCR\&D-SWF-2011-000306. U.S. Department of Energy Separations and Waste Forms Campaign. September.

Jubin, R. T. 2017. Design and Test Plan for an Integrated Iodine Scrubber and Polishing Bed System. NTRD-MRWFD-2018-000209. November 30.

Jubin, R. T., N. R. Soelberg, D. M. Strachan, and G. Ilas. 2012. Fuel Age Impacts on Gaseous Fission Product Capture During Separations. FCRD-SWF-2012-000089 and PNNL-22550. September 21.

Jubin, R. T., D. M. Strachan, and N. R. Soelberg. 2013. Iodine Pathways and Off-Gas Stream Characteristics for Aqueous Reprocessing Plants - A Literature Survey and Assessment. FCRD-SWF2013-000308, ORNL/LTR-2013/383, INL/EXT-13-30119. September 15.

Jubin, R. T., J. A. Jordan, and S. H. Bruffey. 2017b. Performance of Silver-Exchanged Mordenite and Silver-Functionalized Silica-Aerogel Under Vessel Off-gas Conditions. NTRD-MRWFD-2017-000034. Oak Ridge National Laboratory.

Soelberg, N., and T. Watson. 2016. FY-2016 Methyl Iodide Higher NOx Adsorption Test Report. FCRDMRWFD-2016-000353 and INL/EXT-16-40087. Idaho National Laboratory, Idaho Falls, ID

Soelberg, Nick R., Troy G. Garn, Mitchell R. Greenhalgh, Jack D. Law, Robert Jubin, Denis M. Strachan, and Praveen K. Thallapally. 2013. "Radioactive Iodine and Krypton Control for Nuclear Fuel Reprocessing Facilities.” Science and Technology of Nuclear Installations 2013: 702496. http://dx.doi.org/10.1155/2013/702496. 